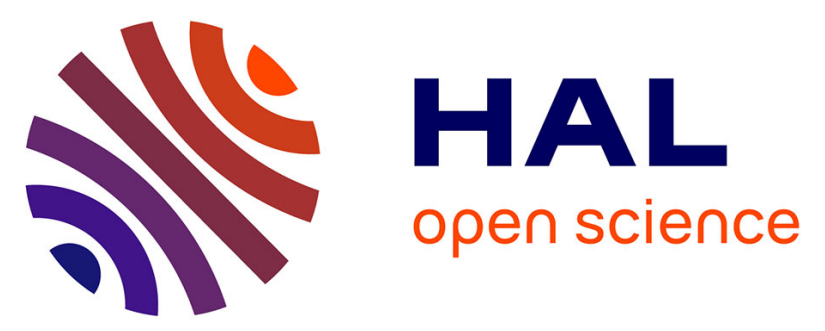

\title{
Genome scans on experimentally evolved populations reveal candidate regions for adaptation to plant resistance in the potato cyst nematode Globodera pallida.
}

Delphine Eoche-Bosy, Matthieu Gautier, Magali Esquibet, Fabrice Legeai, Anthony Bretaudeau, Olivier Bouchez, Sylvain Fournet, Eric Grenier, Josselin Montarry

\section{To cite this version:}

Delphine Eoche-Bosy, Matthieu Gautier, Magali Esquibet, Fabrice Legeai, Anthony Bretaudeau, et al. Genome scans on experimentally evolved populations reveal candidate regions for adaptation to plant resistance in the potato cyst nematode Globodera pallida.. Molecular Ecology, 2017, 26 (18), pp.4700-4711. 10.1111/mec.14240 . hal-01605681v2

\section{HAL Id: hal-01605681 \\ https://hal.inria.fr/hal-01605681v2}

Submitted on 30 Aug 2017

HAL is a multi-disciplinary open access archive for the deposit and dissemination of scientific research documents, whether they are published or not. The documents may come from teaching and research institutions in France or abroad, or from public or private research centers.
L'archive ouverte pluridisciplinaire HAL, est destinée au dépôt et à la diffusion de documents scientifiques de niveau recherche, publiés ou non, émanant des établissements d'enseignement et de recherche français ou étrangers, des laboratoires publics ou privés. 
1 Genome scans on experimentally evolved populations reveal candidate

2 regions for adaptation to plant resistance in the potato cyst nematode

3 Globodera pallida

4

5 D. EOCHE-BOSY ${ }^{1}$, M. GAUTIER ${ }^{2,3}$, M. ESQUIBET ${ }^{1}$, F. LEGEAI ${ }^{4,5}$, A. BRETAUDEAU ${ }^{4,6}$,

6 O. BOUCHEZ ${ }^{7,8}$, S. FOURNET $^{1}$, E. GRENIER ${ }^{1}$ and J. MONTARRY ${ }^{1}$

7

8

9

10

11

12

${ }^{8}$ GenPhySE, Université de Toulouse, INRA, INPT, ENVT, 31326, Castanet-Tolosan, France

16

genomics; selection; virulence

19

Correspondence: Josselin Montarry, IGEPP, INRA, Agrocampus Ouest, Université de Rennes

1, 35650, Le Rheu, France; Fax: +33 2234851 50; E-mail: josselin.montarry@inra.fr

Running title: Molecular signatures of adaptation to resistance 


\section{Abstract}

Improving resistance durability involves to be able to predict the adaptation speed of pathogen populations. Identifying the genetic bases of pathogen adaptation to plant resistances is a useful step to better understand and anticipate this phenomenon. Globodera pallida is a major pest of potato crop for which a resistance QTL, $G p a V_{v r n}$, has been identified in Solanum vernei. However, its durability is threatened as G. pallida populations are able to adapt to the resistance in few generations. The aim of the present study was to investigate the genomic regions involved in the resistance breakdown by coupling experimental evolution and high density genome scan. We performed a whole genome resequencing of pools of individuals (Pool-Seq) belonging to G. pallida lineages derived from two independent populations having experimentally evolved on susceptible and resistant potato cultivars. About 1.6 million SNPs were used to perform the genome scan using a recent model testing for adaptive differentiation and association to population-specific covariables. We identified 275 outliers and 31 of them, which also showed a significant reduction of diversity in adapted lineages, were investigated for their genic environment. Some candidate genomic regions contained genes putatively encoding effectors and were enriched in SPRYSECs, known in cyst nematodes to be involved in pathogenicity and in (a)virulence. Validated candidate SNPs will provide a useful molecular tool to follow frequencies of virulence alleles in natural $G$. pallida populations and define efficient strategies of use of potato resistances maximizing their durability. 


\section{Introduction}

Because of the threat caused by crop pathogens to global food security, control methods to limit yield losses and maintain sustainable productions are needed. If pesticides have been successfully employed for years, the current societal and political demand for a reduction of their use is strong. In most cases, resistant cultivars are now the chosen alternative, as they can be highly effective, organism-specific, economically and environmentally sustainable. However, this control method can be limited by evolutionary capacities of targeted pathogens, which can adapt to plant resistances (McDonald \& Linde 2002). Resistance breakdowns have been documented in a wide range of crop pathogens, such as virus, bacteria, nematodes, fungi or oomycetes (e.g., Castagnone-Sereno 2002; McDonald \& Linde 2002; Janzac et al. 2009), whereas the development of resistant cultivars is a long process, in the order of decades, i.e. usually longer than the time needed for pathogen populations to overcome resistances. Consequently, the design of strategies allowing an increase in resistance durability has been a major goal in plant pathology research over the last 50 years, especially as resistance genes or QTLs remain a scarce resource. To be efficient, such strategies have to integrate knowledge on the adaptation of pathogen populations to the selective pressure imposed by the resistant plant. Consequently, a significant step towards a better management of resistance durability could be taken by identifying the genetic determinants of adaptation to plant resistances, which would represent direct predictors allowing to link dynamics and genetics of resistance breakdown.

Plant-parasitic nematodes are major agricultural pathogens causing severe damages in crops worldwide (Nicol et al. 2011), but sources of resistance against them remain scarce. Several studies have been conducted to optimize the management of these resistances (DjianCaporalino et al. 2014; Barbary et al. 2015). Cyst nematodes are among the most 
economically damaging plant-parasitic nematodes. Over the last few years, increased knowledge about characteristics of cyst nematode populations allowed to better predict the global evolutionary potential of these populations. In particular it was showed that cyst nematode populations represent a real threat to the durability of plant resistances due to an important passive dispersion (Picard et al. 2004; Plantard \& Porte 2004; Alenda et al. 2014) and favored expression of recessives virulence genes due to inbreeding (Montarry et al. 2015). The adaptation speed of nematode populations would also be modulated by the number and the nature of genetic mutations required to overcome the plant resistance, and by the presence and, if any, the frequency, of virulent individuals in fields.

The cyst nematode Globodera pallida (Stone) is a major pest of potato crop (Oerke et al. 1994; van Riel \& Mulder 1998) and Solanum vernei, a wild potato species, is an interesting source of resistance against G. pallida as it is highly effective. The resistance, which leads to the development of most nematodes into adult males, is explained at $61 \%$ by the major QTL $G p a V_{v r n}$ mapped on the potato chromosome V (Rouppe van der Voort et al. 2000). This source of resistance is to date the only one exploited in commercial potato cultivars at the European level. The resistant cultivar Iledher, carrying $G p a V_{v r n}$, has been registered in 2009 in the French catalogue as the first cultivar showing a high level of resistance to G. pallida. However, Fournet et al. (2013) highlighted that G. pallida populations were able to completely overcome the resistance of Iledher in only few generations in experimental evolution. Identifying the determinants of virulence thus appears to be crucial to better anticipate the speed of adaptation of $G$. pallida populations.

In organisms with relatively small genomes, such as RNA viruses with $10-15 \mathrm{~kb}$ genomes, it is possible since several years to sequence the entire genome and to directly compare sequences of virulent and avirulent strains in order to find the mutation responsible 
for resistance adaptation (Meshi et al. 1988; Díaz et al. 2004; Ayme et al. 2006; Mardis 2008; Janzac et al. 2010). However, this approach cannot be considered in eukaryotic organisms whose genomes range from one to hundreds of thousands megabases. Genome scans represent an efficient alternative to target genomic regions involved in adaptation in such organisms, as they analyze genome-wide variations at the light of theoretical predictions about the effects of selection, in order to detect locus specific signatures of positive directional selection (Luikart et al. 2003; Storz 2005). Despite their strong potential to elucidate the genetic bases of adaptation, genome scans have never been used to identify the determinants of virulence in nematodes. However, Bekal et al. (2015) recently opened the way for population genomic approach in cyst nematodes. They performed a whole genome allelic imbalance analysis of SNP in Heterodera glycines inbred lines grown in the laboratory for over 30 generations on resistant and susceptible soybean plants. This study revealed two new candidate virulence genes: $H g B i o B$, a gene encoded biotin synthase and $H g S L P-1$, a gene that appears to have entered $H$. glycines genome via horizontal gene transfer and which encode a protein containing a putative SNARE domain. Virulence is based on sequence polymorphisms for the first gene and on a reduced copy number for the second gene. In potato cyst nematodes, (a)virulence genes known to date were identified only through candidate gene approaches. In Globodera rostochiensis, the venom allergen Gr-VAP1 was identified as an avirulence gene product triggering a cell death response in tomato (Lycopersicon esculentum) plants containing the $C f$-2 and Rcr3pim resistant genes (LozanoTorres et al. 2012, 2014). In G. pallida, only one avirulence gene, Gp-RBP-1, coding for a SPRYSEC which interacts with the GPA2 resistant protein in potato, has been described (Sacco et al. 2009). Virulence is due to a single amino-acid polymorphism, however this mutation is widely distributed in European populations (Carpentier et al. 2012) and therefore 
potato carrying Gpa2 resistance gene is of very limited interest for control of G. pallida. On the contrary, the resistant cultivar Iledher shows a high level of resistance to a wide range of European G. pallida populations.

The aim of the present study was to investigate the G. pallida genomic regions involved in the breakdown of the resistance of potato cultivar Iledher. By analyzing microsatellite data, Eoche-Bosy et al. (2016) already showed that a genome scan on the $G$. pallida lineages coming from the experimental evolution performed by Fournet et al. (2013) was feasible. Here, we took advantage of the same biological material to perform a high density genome scan using data from a whole genome resequencing of pools of individuals (Pool-Seq, Futschik \& Schlötterer 2010; Zhu et al. 2012; Ferretti et al. 2013; Gautier et al. 2013; Schlötterer et al. 2014) and a recent model testing for adaptive differentiation and association to population-specific covariables (BayPass, Gautier 2015).

\section{Materials and methods}

Study system: Globodera pallida

Globodera pallida is a gonochoristic diploid organism with obligate sexual reproduction, which achieves one generation per year in European climatic conditions (Jones 1950). This obligate parasite enters the plant roots as second-stage juveniles (J2) and establishes a specialized feeding structure, the syncytium (Jones \& Northcote 1972), which is a severe nutrient sink for the plant. In this species, sex is environmentally determined and depends on the size and efficiency of the syncytium (Sobczak \& Golinowski 2011). Adult males leave the root to mate females, which can be fertilized by several males (Green et al. 1970; Triantaphyllou \& Esbenshade 1990). After mating, the females continue to feed from the 
syncytium and when eggs development is completed, they die and form a cyst, enclosing hundreds of eggs, which can stay viable for several years in soils.

The genome of G. pallida has been recently sequenced (Gpal.v1.0, Cotton et al. 2014). It is available as an assembly of $124.7 \mathrm{Mb}$ in 6,873 scaffolds, with a N50 of $122 \mathrm{~kb}$ and a GC content of $36.7 \%$ (Cotton et al. 2014). Combining transcriptomic data with manual curation, a total of 16,419 genes were predicted. The genome of $G$. rostochiensis has also been recently sequenced (nGr.v1.0, Eves-van den Akker et al. 2016) and could be a more accurate representation of a Globodera genome, as suggested by its higher completeness and low level of gene duplication. This genome is available as an assembly of $95.9 \mathrm{Mb}$ in 4,377 scaffolds, with a N50 of $88 \mathrm{~kb}$ and a GC content of $38.1 \%$. Annotation of G. rostochiensis genome could also be of better quality as a manual annotation phase followed the initial phase of automated annotation, resulting in the prediction of 14,378 genes.

\section{Selection of virulent and avirulent $\mathrm{G}$. pallida lineages}

This study relies on the biological material coming from the experimental evolution performed by Fournet et al. (2013). Briefly, nematode lineages were established from cysts of two French natural G. pallida populations, SM (near Saint-Malo, Brittany, north-western France) and $\mathrm{N}$ (from the island of Noirmoutier, western France) coming from infested fields (Fig. 1). The lineages used here were obtained by rearing both populations during eight successive cycles (i.e. eight generations) on the susceptible potato cultivar Désirée (D) and on the resistant cultivar Iledher (I). The present study was conducted with the eighth generation of the four lineages: two lineages adapted to the resistance of Iledher (named hereafter SMI and NI), and two lineages which remained unadapted (named hereafter SMD and ND). 


\section{Pool sequencing}

As the amount of DNA in a single G. pallida individual is very low, pooling individuals from a same lineage was an efficient way to increase the amount of DNA while allowing the accurate estimation of population allele frequencies (e.g., Gautier et al. 2013). To accurately represent the genetic variability of each lineage, we chose to sample individuals from different cysts, rather than different individuals from a same cyst, to constitute the pools. We therefore sampled 300 cysts in each lineage, which was the maximum available, and crushed them individually in sterile water. Two J2 (siblings) were sampled from each cyst and attributed to two different pools, resulting in two pools of 300 individuals for each lineage, i.e. two biological replicates. Water in samples was then vacuum-evaporated in a heated Speed Vac Concentrator (MiVac, Genevac Ltd., Ipswich, UK). As the cuticle of the nematode could prevent the lysis of tissues by the proteinase $\mathrm{K}$, samples were stored at $-80^{\circ} \mathrm{C}$ during two hours and then rapidly heated at ambient temperature, just before DNA extraction. DNA was extracted directly from each pool using Qiagen DNeasy Blood and Tissue Kit (Qiagen, Hilden, Germany) following the manufacturer's instructions. A pooled DNA extraction has been favored over an individual DNA extraction following by a pooling of the DNA in equimolar proportions because this last strategy can lead to heterogeneity in the amount of each individual DNA due to measurement (poor estimations of individuals DNA concentration) or pipetting errors (Gautier et al. 2013). Extracted genomic DNA was quantified using a Qubit® 2.0 Fluorometer (Invitrogen, Carlsbad, CA, USA) and quality was estimated using a Nanodrop® ND-2000 Spectrophotometer (Thermo Fisher Scientific, Wilmington, DE, USA). The DNA samples conformed to the required purity criteria (A260/A230 and A260/A280 > 1.8) for gDNA library preparation for sequencing, but not to the required concentration criterion, as the amount of DNA obtained from a 300 individuals 
pool was still very low (i.e. $17 \mathrm{ng}$ of DNA per pool on average). Paired-end libraries were therefore constructed from the totality of DNA available in each pool (i.e. each biological replicate in each lineage) contained in $100 \mu \mathrm{L}$ AE buffer (Qiagen), using the TruSeq Nano DNA Sample Preparation Kits (Illumina, San Diego, CA, USA), according to the manufacturer's instructions. Briefly, DNA was fragmented using a Covaris M220 ultrasonicator (Covaris, Woburn, MA, USA) and, after a purification step, end repaired. A bead-based size selection was performed, then DNA was A-tailed and ligated to indexed sequencing adapters (60 bp on each side), each biological replicate being identified by a different index. After a double-purification, libraries were enriched by eight PCR cycles, followed by a final purification. Library profiles were controlled using a DNA High Sensitivity chip on a BioAnalyzer 2100 (Agilent Technologies, Santa Clara, CA, USA), showing that the average size of the eight libraries was 513 bp (i.e. average insert size of 493 bp). Libraries were then quantified by qPCR on ABI7900HT (Applied Biosystems) in order to pool them in equimolar proportions. The final pool was again quantified by qPCR on $\mathrm{ABI} 7900 \mathrm{HT}$ in order to load on each lane a volume corresponding to a DNA concentration of $8 \mathrm{pM}$. In order to sequence the eight libraries at an expected 150X coverage depth, four lanes were necessary. Sequencing was performed on an Illumina HiSeq ${ }^{\mathrm{TM}} 2500$ platform (Illumina). Three lanes were sequenced with HiSeq v4 reagent kits (HiSeq PE Cluster Kit v4 and HiSeq SBS Kit v4, Illumina) providing $2 \times 125$ bp paired-end reads and the fourth lane was sequenced with TruSeq v3 reagents kit (TruSeq PE Cluster Kit v3 and TruSeq SBS Kit v3, Illumina) providing 2x100 bp paired-end reads. Libraries preparation and sequencing were performed at the GeT-PlaGe France Genomics sequencing platform (Toulouse, France). All the obtained data were submitted to the BBRIC Archive network (https://bbricarchive.toulouse.inra.fr/web/index.html) in Project Gpool. 
Reads from the 64 fastq files (4 lineages x 2 biological replicates x 4 lanes x 2 (paired-end))

were aligned to the G. pallida reference genome using Bowtie2 version 2.1.0 (Langmead et al. 2009; Langmead \& Salzberg 2012) with default parameters. Duplicate reads were removed using Picard version 1.122.0 (http://broadinstitute.github.io/picard/) and remaining reads were realigned around indels using Realigner Target Creator and Indel Realigner from the Genome Analysis Toolkit, GATK version 2.8.0 (McKenna et al. 2010; DePristo et al. 2011; Van der Auwera et al. 2013). The 32 BAM files obtained were merged in a single mpileup file using SAMtools MPileup version 0.1.19 (Li et al. 2009) with minimum mapping quality and minimum base quality set to 20 . The whole previous workflow was performed on the Galaxy platform (https://galaxyproject.org/, Blankenberg et al. 2010). The mpileup file was further processed to perform SNP calling and derive read counts for each alternative base, after discarding bases with a Base Alignment Quality score below 25. Genomic positions kept in the dataset had to show only two different bases across all the samples, however, the triallelic positions for which the third allele was represented by only one read were included in the analysis as bi-allelic SNPs (after filtering the third allele as a sequencing error). To evaluate the reproducibility of the sequencing results across the technical replicates (sequencing lanes), we carried out a Principal Component Analysis (PCA) based on the allele frequency counts (Fig. S1, Supporting information). A last filtering step based on the coverage and the minimum allele count (MAC) was performed: a SNP was kept in the dataset if i) it had a coverage of more than 30 reads and less than 300 reads (corresponding approximately to the $95 \%$ percentile of the empirical coverage distribution) in each sample and ii) the minor allele was represented by at least two reads in two different pool samples. 
To detect genomic signatures of selection, we used the package BayPass version 2.1 (Gautier 2015) that provides a reimplementation of the Bayesian hierarchical model initially proposed by Coop et al. (2010) and includes several extensions that improve accuracy and decision criteria. The underlying BayPass framework allows both to identify overly differentiated SNPs (candidate for adaptive selection) in a robust fashion, through the computation of the $X t X$ genetic differentiation statistics (Günther \& Coop 2013), and to perform genome-wide association with population-specific covariables. The underlying models explicitly account for the covariance structure among the population allele frequencies that originates from the shared history of the populations under study, through the estimation of the population covariance matrix $\Omega$, which renders the identification of SNPs subjected to selection less sensitive to the confounding effect of demography (Bonhomme et al. 2010; Günther \& Coop 2013). BayPass is generic enough to be suited for the analyses of data from experimental evolution in which the allele frequency covariance structure is simpler, and can handle data derived from Pool-Seq experiments (Gautier 2015).

The allele count dataset was analyzed under all the models implemented in BayPass with all the parameter set to default, considering the virulence/avirulence status (coded as a binary variable with value -1 and 1 respectively) of each sample for the association analysis. First, analysis under the core model allowed to estimate the $X t X$ for each SNP that were calibrated after analyzing a pseudo-observed dataset (POD) simulated under the inference model with parameters set equal to those estimated in the real data. Second, we relied on the Bayes Factor (BF) calculated under the auxiliary covariate model to evaluate association of SNPs to the virulent/avirulent status of the lineages. The auxiliary covariate model involves 
the introduction of a binary auxiliary variable to classify each locus as associated or not. This allows to easily compute Posterior Inclusion Probability (and BF) for each locus while explicitly accounting for multiple testing issues. For each SNP, the Bayes Factor (denoted $\mathrm{BF}_{\mathrm{mc}}$ as in Gautier 2015) was expressed in deciban units (dB) via the transformation $10 \log _{10}$ (BF). As a decision rule, we then followed the popular Jeffreys' rule (Jeffreys 1961) that quantifies the strength of evidence (here in favor of association of the SNP with the covariable) as 'strong' when $10 \mathrm{~dB}<\mathrm{BF}<15 \mathrm{~dB}$, 'very strong' when $15 \mathrm{~dB}<\mathrm{BF}<20 \mathrm{~dB}$ and 'decisive' when $\mathrm{BF}>20 \mathrm{~dB}$.

Three independent BayPass analyses were carried out for each model, giving different values to initial seed of the (pseudo-) Random Number Generator. Under the core model in particular, the posterior estimates of $\Omega$ were found almost identical with a FMD distance (Förstner \& Moonen 2003) between each pair of matrices always lower than 0.01. For prioritization purposes, only SNPs that were overly differentiated if $X t X>1 \%$ POD significance threshold and if $\mathrm{BF}_{\mathrm{mc}}>20$ in the three independent analyses were further considered as candidate.

As we were interested in identifying genomic regions involved in the adaptation to Iledher, we precisely had to consider only SNPs showing footprints of selection in the Iledher lineages (SMI and NI) and not in the Désirée lineages. It is in fact possible to pinpoint genomic regions involved in host adaptation (rather than resistance adaptation), which can occur both in nematode lineages having evolved on Iledher and in the ones having evolved on Désirée, as highlighted in Eoche-Bosy et al. (2016). For this purpose, we used the lnRH test (Kauer et al. 2003; Schlötterer \& Dieringer 2005). LnRH is traditionally used for microsatellite datasets, but as it is not based on a particular mutation model (Kauer et al. 2003), it can also be applied to SNP datasets (Mc Evoy et al. 2006; Vasemägi et al. 2012). 
This test, based on the assumption that markers linked to loci under selection will show reduced levels of diversity within populations (Schlötterer \& Dieringer 2005), uses the expected heterozygosity $\mathrm{H}$ to compute the $\operatorname{lnRH}$ statistics. We merged allelic counts of biological replicates and derived from it allelic frequencies at each SNP in SMI, SMD, NI and ND. We computed the lnRH statistic for each locus in lineage pairs SMI/SMD and NI/ND by calculating the natural logarithm $(\mathrm{ln})$ of the gene diversity ratio $\left[\left(1 /\left(1-\mathrm{H}_{\text {lineagee }}\right)\right)^{2}-1\right] /[(1 /(1-$ $\left.\mathrm{H}_{\text {lineage2) }}\right)^{2}$-1]. For lineages with monomorphic loci, one different allele was added to one individual, as null values of heterozygosity prevent the estimation of $\operatorname{lnRH}$ due to division by zero (Kauer et al. 2003). LnRH estimates were standardized to obtain a mean of 0 and a standard deviation of 1 . As the $\operatorname{lnRH}$ is approximately normally distributed under the null hypothesis of neutrality (Schlötterer \& Dieringer 2005), loci with lnRH values lower than 1.96 were considered outliers at the 0.05 threshold, indicating reduced variability in SMI and NI lineages as compared to SMD and ND, respectively. Only outliers in both lnRH pairwise comparisons were considered, and common outliers to BayPass and $\operatorname{lnRH}$ were retained to further investigation of their genic environment.

\section{Genic environment of outlier loci}

We searched for predicted genes located in a window of $120-\mathrm{kb}$ around outlier loci (60-kb either side) in the annotated G. pallida genome. The choice of this value was based on the AFLP-based genetic linkage map of G. rostochiensis giving a physical:genetic distance ratio

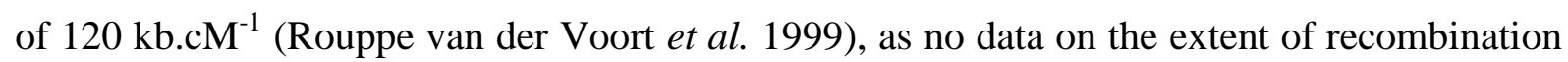
and linkage disequilibrium was available in G. pallida. As the majority of virulence factors identified in plant parasitic nematodes are effectors (Haegeman et al. 2012; Mitchum et al. 2013), we searched as a priority for genes coding for secreted proteins, i.e. harboring N- 
terminal signal peptides in the predicted proteins, using SIGNALP v4.1 (Petersen et al. 2011).

We also performed a BLAST search of the predicted genes against the annotated $G$. rostochiensis genome in order to potentially obtain more precise information on their functional annotation. Eves-van den Akker et al. (2016) identified in G. rostochiensis and subsequently in G. pallida genomes a dorsal gland promoter element motif, termed DOG Box, which may be a strong predictor of secretion, and thus likely effector function. We thus searched for the presence of the predicted genes identified around outlier loci in the G. pallida putative DOG effectors list established by Eves-van den Akker et al. (2016).

\section{Results}

Sequencing, mapping and SNP calling

Sequencing was carried out on duplicates of the lineages SMI, SMD, NI and ND. Despite the low amount of DNA used for each lineage, the generated sequencing data corresponded to the expectations from a quantitative and qualitative point of view. Sequencing produced two billion reads, i.e. 62.5 million reads/sample (biological replicate)/lane, and 76\% mapped on the G. pallida reference genome, but $24 \%$ of these mapping reads mapped more than once on the genome. Duplicate filtering resulted in removing $13.5 \%$ of mapped reads. Remaining reads covered $95 \%$ of the ungapped assembly at an average depth of 34X/sample/lane. Processed mpileup contained 2,383,040 SNPs. PCA based on the allele frequency counts showed that the main axes of variation of genetic variability across the different samples were clearly associated with (i) the population origin and (ii) the virulence status. A very low variation was observed among the sequencing replicates in each pool sample. This prompted us to merge allele count data from the four sequencing replicates (lanes) for each of the eight pool samples (Fig. S1, Supporting information). The final dataset filtered on coverage and 
MAC consisted of read count data for 1,631,158 SNPs in the eight different selected lineages, corresponding to a density of polymorphic sites of $16 / \mathrm{kb}$ on average.

\section{Genome scan for adaptive divergence and association with the virulent/avirulent status}

Analysis of the dataset under the BayPass core model allowed us to estimate the scaled covariance matrix of population allele frequencies $\Omega$ that quantifies the genetic relationship among each pairs of populations. The resulting estimates of $\Omega$ accurately reflected the known structure between samples, i.e. a clustering at the higher level by population geographical origin, then by the virulence status and finally by biological replicate within each lineage (Fig. 2). $X t X$ for each SNP were also estimated and calibrated by analyses of a POD containing 1,600,000 SNPs. At the 1\% POD significance threshold, about 33,000 SNPs were identified as overly differentiated (Fig. 3). However, analysis under the auxiliary covariate model drastically reduced this outlier list, as less than 400 had also a $\mathrm{BF}_{\mathrm{mc}}<20(355,361$ and 357 SNPs in each analysis, respectively) (Fig. 3). Overall, 275 outliers were shared by the three analyses (outlier loci found in only one or two analyses actually exhibited $X t X$ and/or $\mathrm{BF}_{\mathrm{mc}}$ values close to the thresholds, which explains that they were not found in all analyses). Among these 275 SNPs showing an increase of genetic differentiation between Iledher and Désirée lineages, 31 of them also showed a decrease of genetic diversity in both SMI and NI lineages (Fig. 4) as identified by $\operatorname{lnRH}$.

\section{Genic environment of outlier loci}

The 31 selected outlier loci were distributed on 23 different scaffolds. Among these outlier loci for which the genic environment has been investigated, three outliers were located on scaffolds which do not harbor any predicted gene, 16 were located in intergenic area and 12 
were directly located into genes (Table S2, Supporting information). Among the latter, five were located in exons, and four of them corresponded to synonymous mutations. The outlier SNP located on the scaffold 1777 corresponded to a non-synonymous mutation that changes an arginine into a histidine in GPLIN_001438500, which is annotated as a transcribed hypothetical protein. Despite the fragmentation of the G. pallida genome in numerous scaffolds that precluded a clear analysis of the physical distances among most of the identified outliers, it appeared that several outlier loci were sometimes found in the same scaffold. The most significant was the scaffold 988 which contains four outlier SNPs close to each other (< $200 \mathrm{bp})$. Four other scaffolds $(44,85,182$ and 283) harbored outlier SNPs close to each other (<200 bp) and a fifth scaffold (66) harbored also two outlier SNPs but that are $75 \mathrm{~kb}$ apart. The number of outlier SNPs found in a scaffold was not dependent on the size of this scaffold: for instance, scaffold 988, which is one of the smallest scaffold of interest identified, contains four outlier loci. Overall, 258 predicted genes were identified in a 120-kb window around the 31 outlier loci (Table S2, Supporting information). About 47\% (121) of them have unknown function in G. pallida, but 15 harbored a signal peptide, indicating that they potentially encode for secreted proteins, and one, GPLIN_000314000, is similar to an effector in G. rostochiensis (Cotton et al. 2014). Fourteen predicted genes with known functions also harbored a peptide signal. Fifteen genes coding for proteins harboring a SPRY domain were found at the proximity of eight outlier loci, and three of them were paralog of SPRYSECs (Secreted protein with a SPRY domain), which are known in nematodes of the genus Globodera to be involved in pathogenicity but also in (a)virulence (Rehman et al. 2009; Sacco et al. 2009). Two of them, located on scaffolds 182 and 782, were paralog of RBP-1, the only virulence gene identified in G. pallida (Sacco et al. 2009; Carpentier et al. 2012). It is likely that some of the other genes coding for proteins harboring a SPRY domain could 
actually be SPRYSECs, the absence of signal peptide being not ascertained as they are 5' truncated (N's region) in the reference genome. Other genes were also interesting as they encode proteins which have functions linked to G. pallida pathogenicity, e.g., cell wall modifying proteins, or they encode proteins which are known to be secreted by the dorsal pharyngeal gland of $G$. pallida. The pharyngeal glands are cells in which effectors are produced, and thus can be regarded as a toolbox for infection (Eves-van den Akker \& Birch 2016). Cyst nematodes have two sets, subventral and dorsal: the former are primarily active while the nematode migrates through host tissue, while the latter are primarily active during the sedentary parasitic stages (Endo 1987; von Mende 1997; Davis et al. 2000). Some genes with unknown function in G. pallida had homologues with predicted function in $G$. rostochiensis genome, part of them being putatively paralog of SPRYSECs or involved in pathogenicity. Three predicted genes (GPLIN_000832500, GPLIN_001056700 and GPLIN_001258100) harbored DOG Boxes in their promoter region, two of them having unknown function and the third coding for a SPRYSEC protein.

\section{Discussion}

In this study, we investigated Globodera pallida genomic regions involved in the adaptation to the QTL $G p a V_{v r n}$, a resistance factor against this potato parasite, by performing a genome scan on Pool-Seq data derived from experimentally evolved lineages, adapted or not to the resistant potato cultivar Iledher.

Elucidating the molecular bases of virulence is a central challenge in nematology. So far, a few plant-nematode interactions have been studied to characterize the molecular determinants of (a)virulence. In G. pallida, only one virulence gene has been described (Sacco et al. 2009; Carpentier et al. 2012). A priori methods based on candidate genes to 
identify new or unknown virulence genes are therefore not the most adapted ones at the moment. Our study is the first to exploit genome scan to target genetic bases of adaptation to plant resistance in nematode populations. We demonstrated in a previous study the feasibility of a genome scan approach on our specific biological materiel coming from short experimental evolution (Eoche-Bosy et al. 2016), which was achieved here by the identification of 275 outlier loci and 31 candidates of a strong interest among them, distributed on 23 scaffolds. Several genomic regions are therefore putatively linked to adaptation to the resistance of Iledher, however this number should be put in perspective with respects to the moderate quality of the G. pallida reference genome. In fact, the genome assembly is still relatively fragmented (6,873 scaffolds), which could suggest that different genomic regions identified as outliers in our study could in fact form only one or a few. Evesvan den Akker et al. (2016) highlighted that some effector islands identified in $G$. rostochiensis genome were split across different scaffolds in G. pallida genome. This prevents to make realistic assumptions on the number of genes that could be involved in the overcoming of Iledher resistance. However, we assume that only a few virulence genes should be involved as few resistance genetic factors are expected in Iledher because of the major effect of the QTL $G p a V_{v r n}$ which is present in the potato cultivar Iledher and the fast overcoming of this resistance observed in experimental evolution that support rather the view of a mono- or oligogenic resistance.

The moderate quality of the genome involved other limitations in mapping of sequencing reads, leading to the loss of a substantial part of the data. First, $24 \%$ of the sequencing reads did not map on the reference genome, while in the same time, the assembly contains $17 \%$ of N's and has a CEGMA completeness score of $74 \%$ for complete genes and 81\% for partial genes (Parra et al. 2007; Eves-van den Akker et al. 2016). This suggests that a 
large part of unmapped reads could actually belongs to the G. pallida genome, but corresponding sequences would be absent from the assemblage. These missing sequences could putatively comprise candidate genomic regions to adaptation. Second, heterozygosity of the reference genome is suspected, as about $24 \%$ of the sequencing reads mapped more than once on the genome, this hypothesis being supported by the difference between the length of the assembly $(124.7 \mathrm{Mb})$ and the estimated genome size (100 Mb). Sequencing data mapping on these genomic regions were further discarded because of poor mapping score due to the multiple positions mapping, and once again, genomic information about these regions and their possible link to resistance adaptation were lost.

Pool-Seq is now commonly adopted in many studies, included population genomics studies (Rubin et al. 2010, 2012; Clément et al. 2013; Ferretti et al. 2013; Fisher et al. 2013), because it provides more accurate estimation of allele frequencies, at reduced sequencing and library preparation costs (Futschik \& Schlötterer 2010; Zhu et al. 2012; Gautier et al. 2013; Rellstab et al. 2013; Schlötterer et al. 2014). Here, we emphasize the interest of using such an quality of our results also relies on library preparation protocol, which fit the recommendations (Rhodes et al. 2014; Kofler et al. 2016). The TruSeq Nano DNA kit has been shown to be highly accurate and even some duplicates were obtained due to the PCR cycles, Kofler et al. (2016) showed that duplicates were also obtained with free-PCR library preparation kits. Nevertheless, Kofler et al. (2016) highlighted the superior impact of the genome quality over the library preparation protocol on the mapping quality. Numbers of individuals in pools and depth of coverage used have also been determined to improve 

allowed us to refine the list of outlier loci. Analysis of association further conducted by running the auxiliary covariate model allowed to retain only SNPs associated with the virulence status of the lineages, and not those corresponding to other selective pressures (e.g., local adaptation), which helped to reduce the risk of a misleading biological interpretation, a main limitation of genome scans (Pavlidis et al. 2012). Moreover, evaluating the reduction of diversity allowed us to refine the outlier loci list to those linked only to the adaptation to the resistant cultivar Iledher. A direct link between those candidate loci and the adaptation to the resistance cannot yet be done at this stage. Indeed, footprints of selection detected in lineages having evolved on Iledher might well be linked to adaptation to the plant resistance or to the plant itself (including all its genetic background). Also, at this stage, we are unable to definitively link the identified SNPs to the resistance factor $G p a V_{v r n}$ or to another resistance factor present in the genetic background of the cultivar Iledher. Although these different situations will only be deciphering by functional validation, there is a strong possibility that at least some of the candidate genomic regions identified in this study are involved in adaptation to Iledher resistance and in particular to its major resistance QTL $G p a V_{v r n}$.

Sixteen over the 31 outlier loci investigated for their genic environment have at least one gene coding for a secreted protein in their neighboring region (even if all secreted proteins are not effectors, all effectors are secreted protein) and several outliers are at the vicinity of genes coding for proteins specifically secreted in the nematode dorsal gland. Particularly, some of these secreted proteins are SPRYSECs effectors which act as a versatile protein-binding platform for the nematodes to target a wide range of host proteins during parasitism including plant resistance proteins (Rehman et al. 2009; Sacco et al. 2009; DiazGranados et al. 2016). The fact that a considerable part of the outlier loci are found near genes 
coding for a SPRY domain containing protein or even in or at the vicinity of SPRYSECs cannot be only explained by the huge size of this family gene or the prevalence of the SPRY domain in the G. pallida genome. In fact, 299 SPRY domain containing proteins are present in the G. pallida genome (which can be moreover cluster into islands), i.e. 1 for $334 \mathrm{~kb}$, and 30 of them are SPRYSECs, i.e. 1 SPRYSEC for $3.33 \mathrm{Mb}$ (Mei et al. 2015; Eves-van den Akker et al. 2016). When looking at the genic environment of outlier loci, we explored a total of $2 \mathrm{Mb}$ of the genome and we identified 15 SPRY domain containing proteins, i.e. 1 for 133 $\mathrm{kb}$, and 3 SPRYSECs, i.e. 1 for $660 \mathrm{~kb}$. This is more than expected by chance in both cases and therefore support the view that some SPRYSEC proteins should be well indeed involved in the adaptation of G. pallida to Iledher.

It can be noticed that the $\operatorname{lnRH}$ test also identified, among the 275 outlier loci, six SNPs showing a decrease of genetic diversity in both Désirée lineages (data not shown). These loci were distributed on four scaffolds, different from those on which the 31 outliers were located. Although we did not consider them in this study, those results could further be used to study adaptation to the potato cultivar Désirée. Only one of the 13 microsatellite markers identified as outliers by Eoche-Bosy et al. (2016) was located on the same scaffold as one of the 31 outlier SNPs identified here, and no one was located on the same scaffold as the six outlier SNPs involved in Désirée adaptation. The microsatellite marker Gp235 was indeed located at about $150 \mathrm{bp}$ from the outlier SNP identified here on the scaffold 216 . The fact that the other outlier microsatellites were not found on the same scaffold that outlier SNPs is not surprising, due to the small number of microsatellites used and to the fragmentation of the genome.

By identifying genomic regions putatively involved in the adaptation to the resistance from $S$. vernei, the present study has taken a further step towards understanding and 
identifying the determinants of virulence. In the aim of pinpointing, among the candidate loci, those actually involved in the adaptation to the potato cultivar Iledher, a first step of validation could consist of studying allele frequencies of candidate SNPs in natural populations showing different virulence level to Iledher, which could allow to validate some of them whose variations in allelic frequencies would correlate with variations in virulence level. Even if those loci are not the mutation responsible for the adaptation, they can be enough linked to it to be used as molecular tools to determine virulence allele frequencies in field populations before the deployment of resistant cultivars, and to study more accurately the potential fitness costs or benefits linked to the mutation from avirulence to virulence. Indeed, a recent study suggested that adaptation to Iledher involves an increase of fitness on a susceptible potato cultivar (Fournet et al. 2016). However, this study did not test for competition between avirulent and virulent individuals, because of the lack of molecular markers allowing to follow (a)virulence alleles. And it was shown in the Potato Virus $Y$ that a cost of competitiveness could occur, even in absence of fitness cost in simple inoculation (Janzac et al. 2010). The identified outlier loci will also allow to target more precisely the best candidate genes involved in the adaptation, which will have to be functionally validated.

\section{Acknowledgments}

The authors gratefully acknowledge D. Mugniéry and M.C. Kerlan who took part in the experimental evolution, L. Renault, S. Bardou-Valette, C. Porte and D. Fouville who helped for the protocol elaboration and the pooled samples preparation, and M. Vidal for its help in libraries preparation. DEB is supported by the INRA department SPE and the Région Bretagne through a three year PhD grant. 


\section{References}

Alenda C, Montarry J, Grenier E (2014) Human influence on the dispersal and genetic structure of French Globodera tabacum populations. Infection, Genetics and Evolution, 27, 309-317.

Ayme V, Souche S, Caranta C et al. (2006) Different mutations in the genome-linked protein VPg of Potato virus $Y$ confer virulence on the $p v r 2^{3}$ resistance in pepper. Molecular PlantMicrobe Interactions, 19, 557-563.

Barbary A, Djian-Caporalino C, Palloix A, Castagnone-Sereno P (2015) Host genetic resistance to root-knot nematodes, Meloidogyne spp., in Solanaceae: from genes to the field. Pest Management Science, 71, 1591-1598.

Bekal S, Domier LL, Gonfa B, Lakhssassi N, Meksem K, Lambert KN (2015). A SNARElike protein and biotin are implicated in soybean cyst nematode virulence. PLoS ONE, 10, e0145601.

Blankenberg D, Von Kuster G, Coraor N et al. (2010) Galaxy: a web-based genome analysis tool for experimentalists. Current Protocols in Molecular Biology, 89, 19.10.1-19.10.21.

Bonhomme M, Chevalet C, Servin B et al. (2010) Detecting selection in population trees: the Lewontin and Krakauer test extended. Genetics, 186, 241-262.

Carpentier J, Esquibet M, Fouville D, Manzanares-Dauleux MJ, Kerlan MC, Grenier E (2012) The evolution of the Gp-Rbp-1 gene in Globodera pallida includes multiple selective replacements. Molecular Plant Pathology, 13, 546-555.

Castagnone-Sereno P (2002) Genetic variability of nematodes: a threat to the durability of plant resistance genes? Euphytica, 124, 193-199.

Clément JA, Toulza E, Gautier M et al. (2013) Private selective sweeps identified from nextgeneration pool-sequencing reveal convergent pathways under selection in two inbred Schistosoma mansoni strains. PLoS Neglected Tropical Diseases, 7, e2591.

Coop G, Witonsky D, Rienzo A, Pritchard JK (2010) Using environmental correlations to identify loci underlying local adaptation. Genetics, 185, 1411-1423.

Cotton JA, Lilley CJ, Jones LM et al. (2014) The genome and life-stage specific transcriptomes of Globodera pallida elucidate key aspects of plant parasitism by a cyst nematode. Genome Biology, 15, R43.

Davis EL, Hussey RS, Baum TJ et al. (2000) Nematode parasitism genes. Annual Review of Phytopathology, 38, 365-396.

DePristo MA, Banks E, Poplin R et al. (2011) A framework for variation discovery and genotyping using next-generation DNA sequencing data. Nature Genetics, 43, 491-498.

Díaz JA, Nieto C, Moriones E, Truniger V, Aranda MA (2004) Molecular characterization of a Melon necrotic spot virus strain that overcomes the resistance in melon and nonhost plants. Molecular Plant-Microbe Interactions, 17, 668-675.

Diaz-Granados A, Petrescu AJ, Goverse A, Smant G (2016) SPRYSEC effectors: a versatile protein-binding platform to disrupt plant innate immunity. Frontiers in Plant Science, 7, 1575.

Djian-Caporalino C, Palloix A, Fazari A et al. (2014) Pyramiding, alternating or mixing: comparative performances of deployment strategies of nematode resistance genes to promote plant resistance efficiency and durability. BMC Plant Biology, 14, 53.

Endo BY (1987) Ultrastructure of esophageal gland secretory granules in juveniles of Heterodera glycines. Journal of Nematology, 19, 469-483.

Eoche-Bosy D, Gauthier J, Juhel AS et al. (2016). Experimentally evolved populations of the potato cyst nematode Globodera pallida allow the targeting of genomic footprints of selection due to host adaptation. Plant Pathology, doi: 10.1111/ppa.12646. 
Eves-van den Akker S, Birch PR (2016) Opening the effector protein toolbox for plantparasitic cyst-nematode interactions. Molecular Plant, 9, 1451-1453.

Eves-van den Akker S, Laetsch DR, Thorpe P et al. (2016) The genome of the yellow potato cyst nematode, Globodera rostochiensis, reveals insights into the basis of parasitism and virulence. Genome Biology, 17, 124.

Ferretti L, Ramos-Onsins SE, Pérez-Enciso M (2013) Population genomics from pool sequencing. Molecular Ecology, 22, 5561-5576.

Fischer MC, Rellstab C, Tedder A et al. (2013) Population genomic footprints of selection and associations with climate in natural populations of Arabidopsis halleri from the Alps. Molecular Ecology, 22, 5594-5607.

Förstner W, Moonen B (2003) A metric for covariance matrices. In: Geodesy-The Challenge of the 3rd Millennium (eds Grafarend EW, Krumm FW, Schwarze VS), pp. 299-309. Springer-Verlag, Berlin/Heidelberg, Germany.

Fournet S, Eoche-Bosy D, Renault L, Hamelin FM, Montarry J (2016) Adaptation to resistant hosts increases fitness on susceptible hosts in the plant parasitic nematode Globodera pallida. Ecology and Evolution, 6, 2559-2568.

Fournet S, Kerlan MC, Renault L, Dantec JP, Rouaux C, Montarry J (2013) Selection of nematodes by resistant plants has implications for local adaptation and cross-virulence. Plant Pathology, 62, 184-193.

Futschik A, Schlötterer C (2010) The next generation of molecular markers from massively parallel sequencing of pooled DNA samples. Genetics, 186, 207-218.

Gautier M (2015) Genome-wide scan for adaptive differentiation and association analysis with population-specific covariables. Genetics, 201, 1555-1579.

Gautier M, Foucaud J, Gharbi K et al. (2013) Estimation of population allele frequencies from next-generation sequencing data: pool-versus individual-based genotyping. Molecular Ecology, 22, 3766-3779.

Green CD, Greet DN, Jones FGW (1970) The influence of multiple mating on the reproduction and genetics of Heterodera rostochiensis and H. schachtii. Nematologica, 16, 309-326.

Günther T, Coop G (2013) Robust identification of local adaptation from allele frequencies. Genetics, 195, 205-220.

Haegeman A, Mantelin S, Jones JT, Gheysen G (2012) Functional roles of effectors of plantparasitic nematodes. Gene, 492, 19-31.

Janzac B, Fabre F, Palloix A, Moury B (2009) Constraints on evolution of virus avirulence factors predict the durability of corresponding plant resistances. Molecular Plant Pathology, 10, 599-610.

Janzac B, Montarry J, Palloix A, Navaud O, Moury B (2010) A point mutation in the polymeras Potato Virus $Y$ confers virulence toward the Pvr4 resistance of pepper and a high competitiveness cost in susceptible cultivar. Molecular Plant-Microbe Interactions, 23, 823-830.

Jeffreys H (1961) Theory of Probability, $3^{\text {rd }}$ edn. Oxford University Press, Oxford, UK.

Jones FGW (1950) Observations on the beet eelworm and other cyst-forming species of Heterodera. Annals of Applied Biology, 37, 407-440.

Jones MGK, Northcote DH (1972) Nematode-induced syncytium - a multinucleate transfer cell. Journal of Cell Science, 10, 789-809.

Kauer MO, Dieringer D, Schlötterer C (2003) A microsatellite variability screen for positive selection associated with the "Out of Africa" habitat expansion of Drosophila melanogaster. Genetics, 165, 1137-1148. 
Kofler R, Nolte V, Schlötterer C (2016) The impact of library preparation protocols on the consistency of allele frequency estimates in Pool-Seq data. Molecular Ecology Resources, 16, 118-122.

Langmead B, Salzberg SL (2012) Fast gapped-read alignment with Bowtie 2. Nature Methods, 9, 357-359.

Langmead B, Trapnell Cole, Pop M, Salzberg SL (2009) Ultrafast and memory-efficient alignment of short DNA sequences to the human genome. Genome Biology, 10, R25.

Li H, Handsaker B, Wysoker A et al. (2009) The Sequence Alignment/Map format and SAMtools. Bioinformatics, 25, 2078-2079.

Lozano-Torres JL, Wilbers RH, Gawronski P et al. (2012) Dual disease resistance mediated by the immune receptor $\mathrm{Cf}-2$ in tomato requires a common virulence target of a fungus and a nematode. Proceedings of the National Academy of Sciences of the United States of America, 109, 10119-10124.

Lozano-Torres JL, Wilbers RH, Warmerdam S et al. (2014) Apoplastic venom allergen-like proteins of cyst nematodes modulate the activation of basal plant innate immunity by cell surface receptors. PLoS Pathogens, 10, e1004569.

Luikart G, England PR, Tallmon D, Jordan S, Taberlet P (2003) The power and promise of population genomics: from genotyping to genome typing. Nature Reviews Genetics, $\mathbf{4}$, 981-994.

Mardis ER (2008) The impact of next-generation sequencing technology on genetics. Trends in Genetics, 24, 133-141.

McDonald BA, Linde C (2002) Pathogen population genetics, evolutionary potential, and durable resistance. Annual Review of Phytopathology, 40, 349-379.

McEvoy B, Beleza S, Shriver MD (2006) The genetic architecture of normal variation in human pigmentation: an evolutionary perspective and model. Human Molecular Genetics, 15, R176-R181.

McKenna A, Hanna M, Banks E et al. (2010) The Genome Analysis Toolkit: A MapReduce framework for analyzing next-generation DNA sequencing data. Genome Research, 20, 1297-1303.

Mei Y, Thorpe P, Guzha A et al. (2015) Only a small subset of the SPRY domain gene family in Globodera pallida is likely to encode effectors, two of which suppress host defences induced by the potato resistance gene Gpa2. Nematology, 17, 409-424.

Meshi T, Motoyoshi F, Adachi A, Watanabe Y, Takamatsu N, Okada Y (1988) Two concomitant base substitutions in the putative replicase genes of tobacco mosaic virus confer the ability to overcome the effects of a tomato resistance gene, Tm-1. EMBO Journal, 7, 1575-1581.

Mitchum MG, Hussey RS, Baum TJ et al. (2013) Nematode effector proteins: an emerging paradigm of parasitism. New Phytologist, 199, 879-894.

Montarry J, Jan PL, Gracianne C et al. (2015) Heterozygote deficits in cyst plant-parasitic nematodes: possible causes and consequences. Molecular Ecology, 24, 1654-1677.

Nicol JM, Turner SJ, Coyne DL, den Nijs L, Hockland S, Maafi ZT (2011) Current nematode threats to world agriculture. In: Genomics and Molecular Genetics of Plant-Nematode Interactions (eds Jones J, Gheysen G, Fenoll C), pp. 21-43. Springer, Dordrecht, The Netherlands.

Oerke EC, Dehne HW, Schönbeck F, Weber A (1994) Crop production and crop protection: estimated losses in major food and cash crop. Elsevier Science BV, Amsterdam, The Netherlands. 
Parra G, Bradnam K, Korf I (2007) CEGMA: A pipeline to accurately annotate core genes in eukaryotic genomes. Bioinformatics, 23, 1061-1067.

Pavlidis P, Jensen JD, Stephan W, Stamatakis A (2012) A critical assessment of storytelling: gene ontology categories and the importance of validating genomic scans. Molecular Biology and Evolution, 29, 3237-3248.

Petersen TN, Brunak S, von Heijne G, Nielsen H (2011) SIGNALP 4.0: discriminating signal peptides from transmembrane regions. Nature Methods, 8,785-786.

Picard D, Plantard O, Scurrah M, Mugniéry D (2004) Inbreeding and population structure of the potato cyst nematode (Globodera pallida) in its native area (Peru). Molecular Ecology, 13, 2899-2908.

Plantard O, Porte C (2004) Population genetic structure of the sugar beet cyst nematode Heterodera schachtii: a gonochoristic and amphimictic species with highly inbred but weakly differentiated populations. Molecular Ecology, 13, 33-41.

Rehman S, Postma W, Tytgat T et al. (2009) A secreted SPRY domain-containing protein (SPRYSEC) from the plant-parasitic nematode Globodera rostochiensis interacts with a CC-NB-LRR protein from a susceptible tomato. Molecular Plant-Microbe Interactions, 22, 330-340.

Rellstab C, Zoller S, Tedder A, Gugerli F, Fischer MC (2013) Validation of SNP allele frequencies determined by pooled next-generation sequencing in natural populations of a non-model plant species. PLOS ONE, 8, e80422.

Rhodes J, Beale MA, Fisher MC (2014) Illuminating choices for library prep: a comparison of library preparation methods for whole genome sequencing of Cryptococcus neoformans using Illumina HiSeq. PLoS One, 9, e113501.

Rouppe van der Voort JNAM, van der Vossen E, Bakker E et al. (2000) Two additive QTLs conferring broad-spectrum resistance in potato to Globodera pallida are localized on resistance gene clusters. Theoretical and Applied Genetics, 96, 654-661.

Rouppe van der Voort JNAM, van Eck HJ, van Zandvoort PM, Overmars H, Helder J, Bakker J (1999) Linkage analysis by genotyping of sibling populations: a genetic map for the potato cyst nematode constructed using a 'pseudo-F2' mapping strategy. Molecular and General Genetics, 261, 1021-31.

Rubin CJ, Megens HJ, Barrio AM et al. (2012) Strong signatures of selection in the domestic pig genome. Proceedings of the National Academy of Sciences of the United States of America, 109, 19529-19536.

Rubin CJ, Zody MC, Eriksson J et al. (2010) Whole-genome resequencing reveals loci under selection during chicken domestication. Nature, 464, 587-591.

Sacco MA, Koropacka K, Grenier E et al. (2009) The cyst nematode SPRYSEC protein RBP1 elicits Gpa2- and RanGAP2-dependent plant cell death. PLoS Pathogens, 5, e1000564.

Schlötterer C, Dieringer D (2005) A novel test statistic for the identification of local selective sweeps based on microsatellite gene diversity. In: Selective Sweep (ed. Nurminsky D), pp. 55-64. Landes Bioscience, Georgetown, USA.

Schlötterer C, Tobler R, Kofler R, Nolte V (2014) Sequencing pools of individuals - mining genome-wide polymorphism data without big funding. Nature Review Genetics, 15, 749763.

Sobczak M, Golinowski W (2011) Cyst nematodes and syncytia. In: Genomics and molecular genetics of plant-nematode interactions (eds Jones JT, Gheysen G, Fenoil C), pp. 61-82. Springer, Dordrecht, The Netherlands.

Storz JF (2005) Using genome scans of DNA polymorphism to infer adaptive population divergence. Molecular Ecology, 14, 671-688. 
Triantaphyllou AC, Esbenshade PR (1990) Demonstration of multiple mating in Heterodera glycines with biochemical markers. Journal of Nematology, 22, 452-456.

Van der Auwera GA, Carneiro MO, Hartl C et al. (2013) From FastQ data to high confidence variant calls: the Genome Analysis Toolkit best practices pipeline. Current Protocols in Bioinformatics, 43, 11.10.1-11.10.33.

van Riel HR, Mulder A (1998) Potato cyst nematodes (Globodera species) in western Europe. In: Potato Cyst Nematodes: Biology, Distribution and Control (eds Marks RJ, Brodie BB), pp. 271-298. CAB International, Wallingford, UK.

Vasemägi A, Nilsson J, McGinnity P et al. (2012) Screen for footprints of selection during domestication/captive breeding of Atlantic Salmon. Comparative and Functional Genomics, 2012, 628204.

von Mende N (1997) Invasion and migration behaviour of sedentary nematodes. In: Cellular and Molecular Aspects of Plant-Nematodes Interactions (eds Fenoll C, Grundler FMW, Ohl SA), pp. 51-64. Kluwer Academic Publishers, Dordrecht, The Netherlands.

Zhu Y, Bergland AO, González J, Petrov DA (2012) Empirical validation of pooled whole genome population re-sequencing in Drosophila melanogaster. PLoS One, 7, e41901.

\section{Data accessibility}

Sequencing data were submitted to the BBRIC Archive network (https://bbricarchive.toulouse.inra.fr/web/index.html) in Project Gpool.

\section{Author Contributions}

SF performed the experimental evolution. DEB, ME, SF and JM performed the experiments according to a protocol elaborated jointly by DEB, EG and JM. OB performed the Illumina sequencing at the GeT-PlaGe platform (Toulouse, France). DEB, MG, FL and AB analyzed the data. DEB and JM wrote the text and prepared the figures. All authors edited the article and have approved the current version.

\section{Supporting information}

Additional supporting information may be found on the online version of this article.

Figure S1 Principal Component Analysis (PCA) of the sequencing data from eight G. pallida pools sequenced on four lanes (technical replicates), based on read counts at 2,383,040 SNPs. Table S2 Putative functions of the predicted genes located in a $120-\mathrm{kb}$ window centered on the 31 outlier loci on the Globodera pallida genome assembly version Gpal.v1.0 (Cotton et al. 2014). 
Fig. 1 Selection of the four experimental Globodera pallida lineages. Nematode lineages were established from two French natural G. pallida populations, SM (near Saint-Malo, Brittany, north-western France) and N (from the island of Noirmoutier, western France), reared during eight successive cycles (i.e. eight generations) on the susceptible potato cultivar Désirée (D) and on the resistant cultivar Iledher (I). Each sample name indicates its geographical origin (SM for Saint-Malo and N for Noirmoutier) and the potato cultivar on which it evolved (I for Iledher and D for Désirée).

Fig. 2 Inferred relationship among the eight G. pallida lineages represented by a correlation plot and a hierarchical clustering tree derived from the matrix $\Omega$ estimated under the core model. Each sample name indicates its geographical origin (SM for Saint-Malo and $\mathrm{N}$ for Noirmoutier), the potato cultivar on which it evolved (I for Iledher and D for Désirée) and the replicate number (1 or 2$)$.

Fig. $3 \mathrm{SNP} X t X$ as a function of the $\mathrm{BF}_{\mathrm{mc}}$ for association with the virulence status covariable, estimated in one of the three independent analyses. The vertical dotted line represents the $1 \%$ POD significance threshold $(X t X=14.0)$ and the horizontal dotted line represents the $20 \mathrm{~dB}$ threshold for $\mathrm{BF}_{\mathrm{mc}}$. Black dots represent the 275 outlier loci of interest (i.e. outliers for both $X t X$ and $\mathrm{BF}_{\mathrm{mc}}$ values) and red dots represent the 31 outlier loci of strong interest (i.e. outliers also identified with $\ln \mathrm{RH})$.

Fig. 4 Example of increase of genetic differentiation (represented as $X t X$ estimates computed in BayPass across the whole dataset) and decrease of genetic diversity (represented as expected heterozygosity $\mathrm{H}$ in each lineages having evolved on Iledher) in a candidate genomic region. The scaffold represented is the scaffold 988 and the grey line indicates the location of the four outlier SNPs on the scaffold. 
Figure 1 - Eoche-Bosy et al.

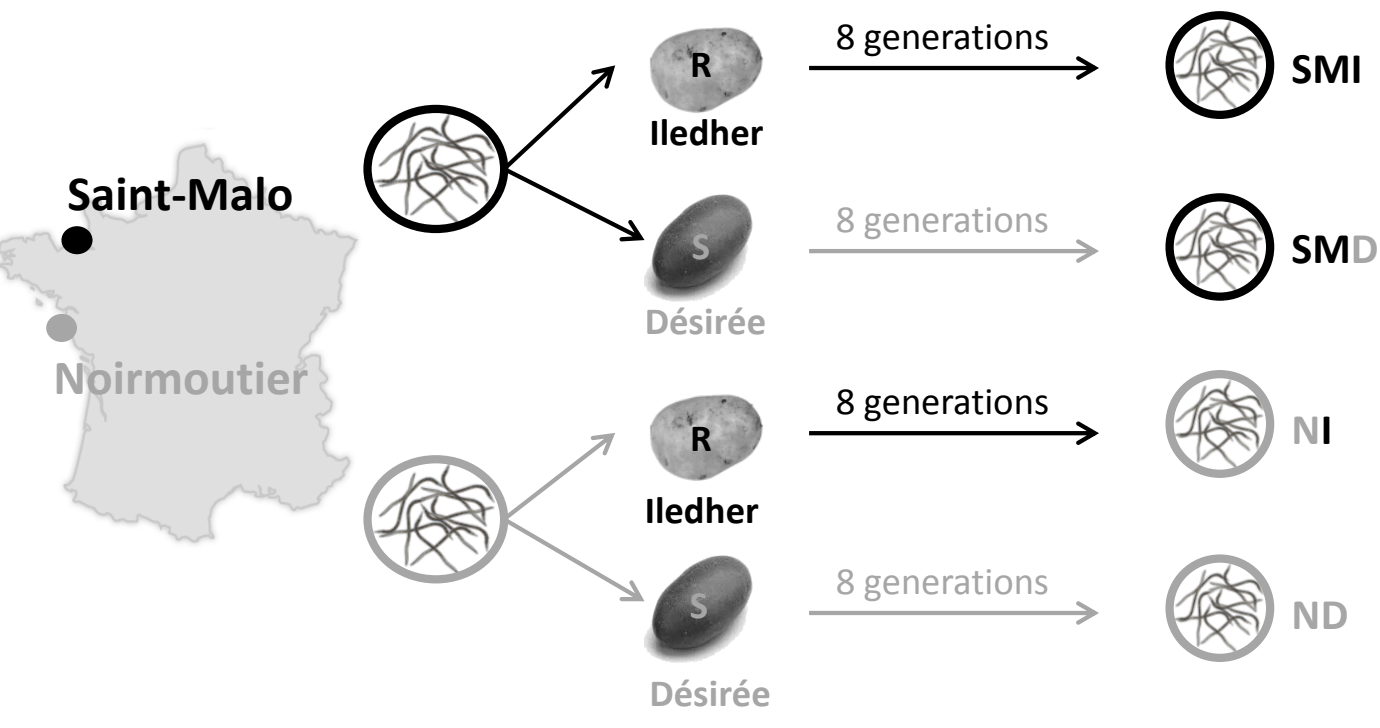


Figure 2 - Eoche-Bosy et al.

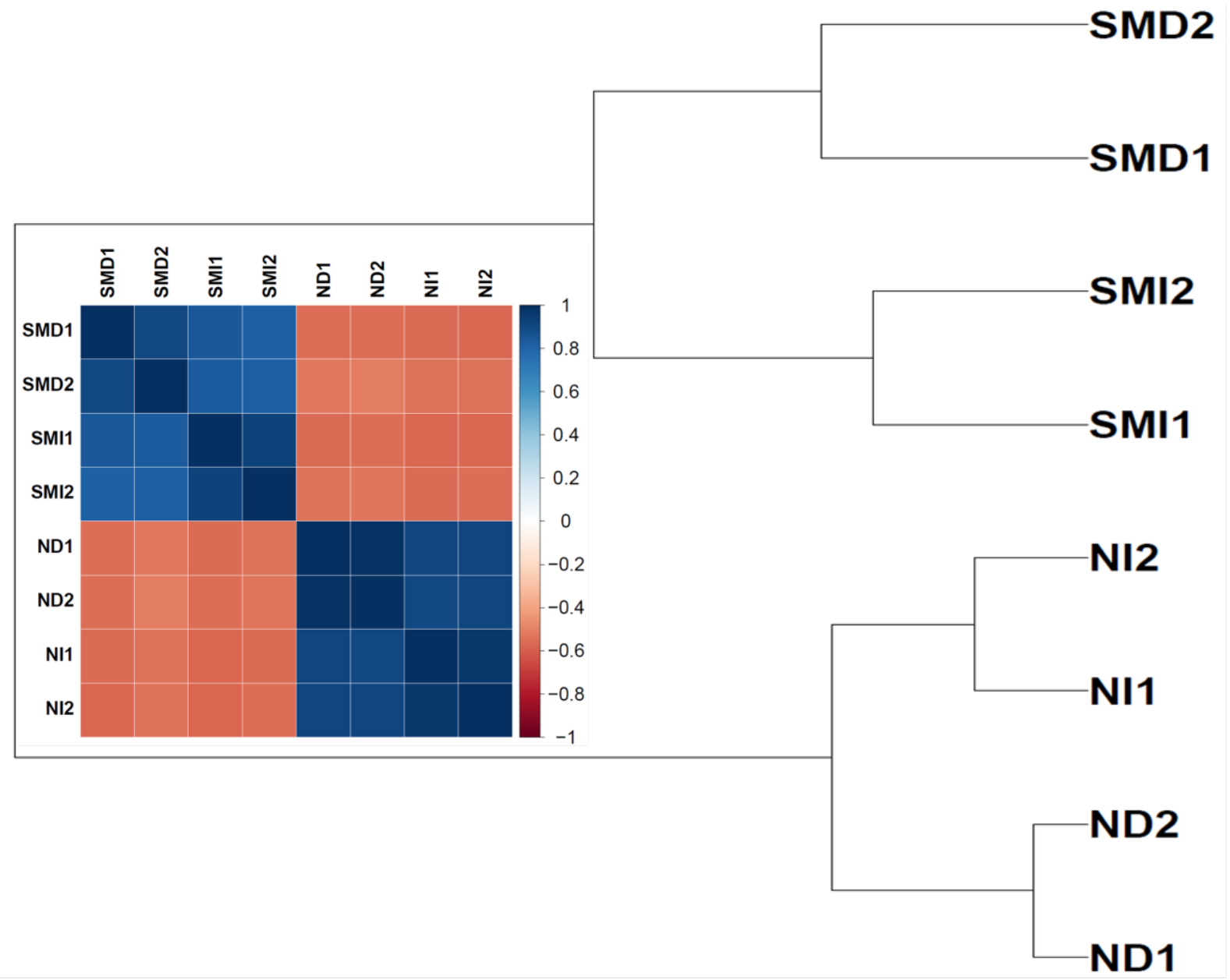


$781 \quad$ Figure 3 - Eoche-Bosy et al.

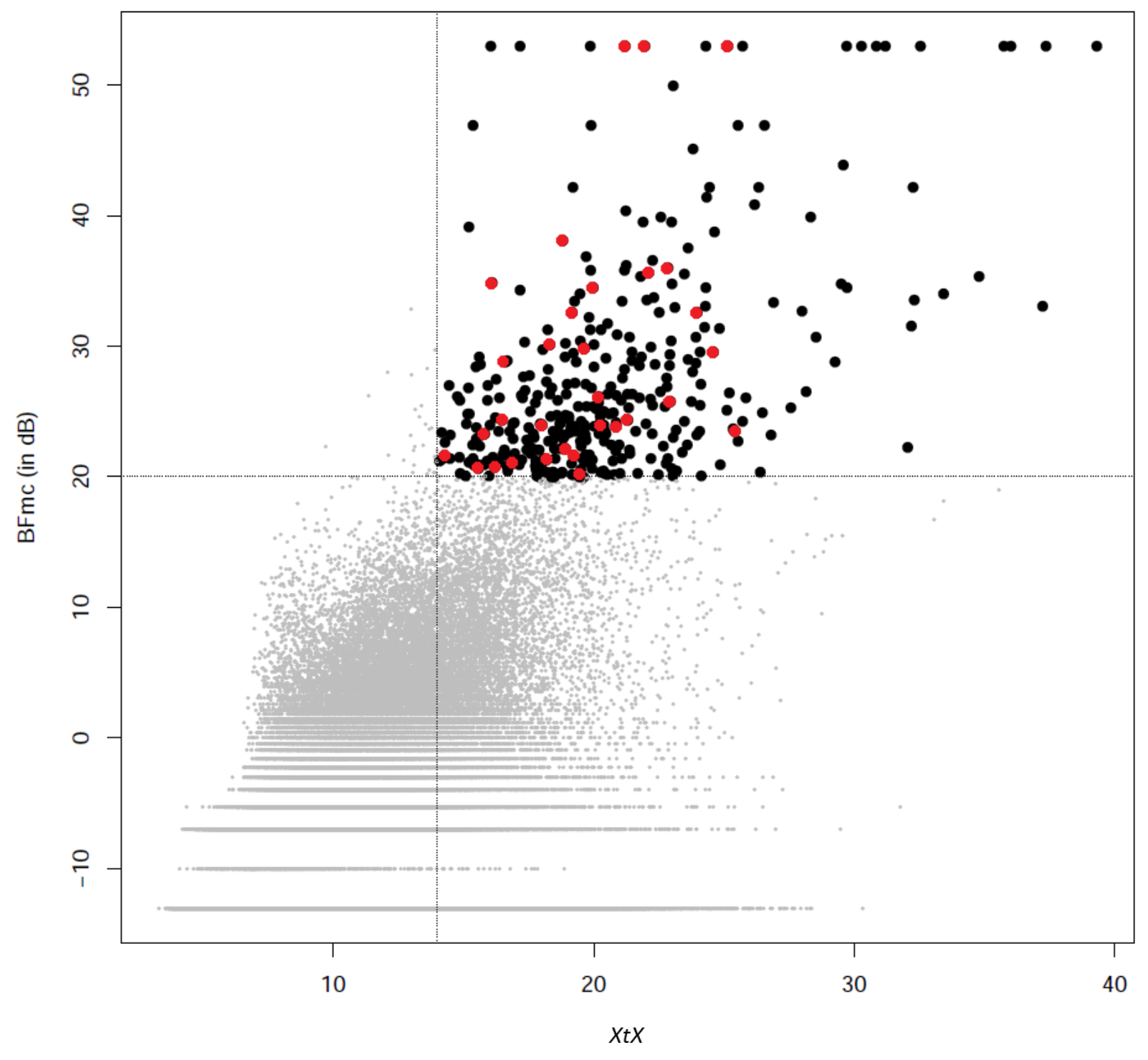


Figure 4 - Eoche-Bosy et al.

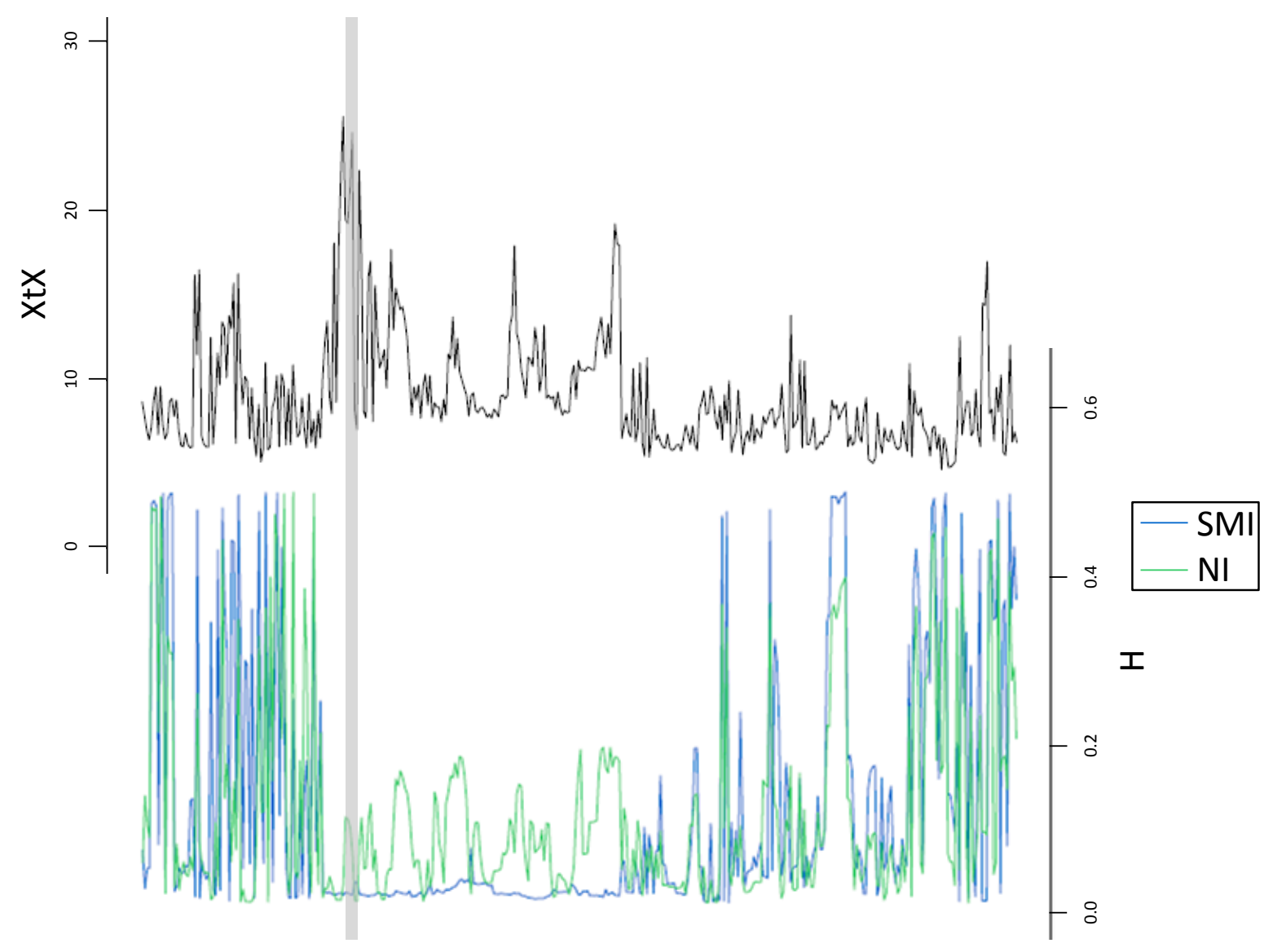




\section{Supplementary Figure S1}

Principal Component Analysis (PCA) of the sequencing data from eight G. pallida pools sequenced on four different lanes (technical replicates), based on read counts at 2,383,040 SNPs. Each sample name indicates its geographical origin (SM for Saint-Malo and N for Noirmoutier), the potato cultivar on which it evolved (I for Iledher and D for Désirée), the number of the biological replicate ( 1 or 2$)$ and the number of the lane (L) on which it has been sequenced. The first axis explains $32.61 \%$ of the variance and clusters the samples according to the population geographical origin. Even if the second and third axes explain a small part of the variance, i.e. $4.41 \%$ for PC2 and $4.22 \%$ for PCA3, they tend to cluster $\mathrm{N}$ and SM samples, respectively, according to their virulence status. Note however that for each of the eight pools, replicate sequenced on the first sequencing lane systematically depart from the three others. This patterns most probably results from a lower sequencing coverage for lane 1 (that was sequenced in $2 \times 100$ bp paired end) compared to the three others (that were sequenced in $2 \times 125$ bp paired-end)

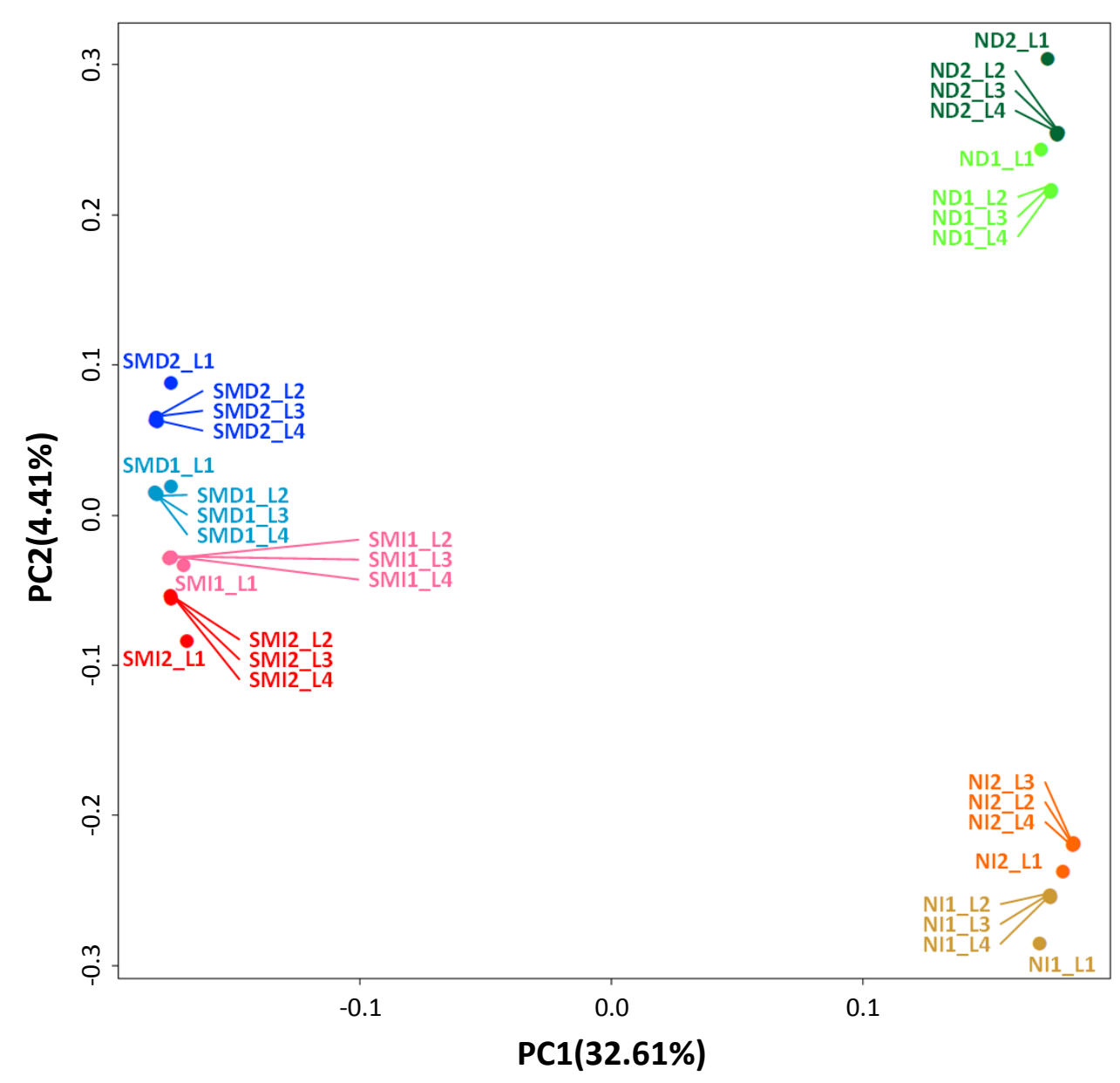




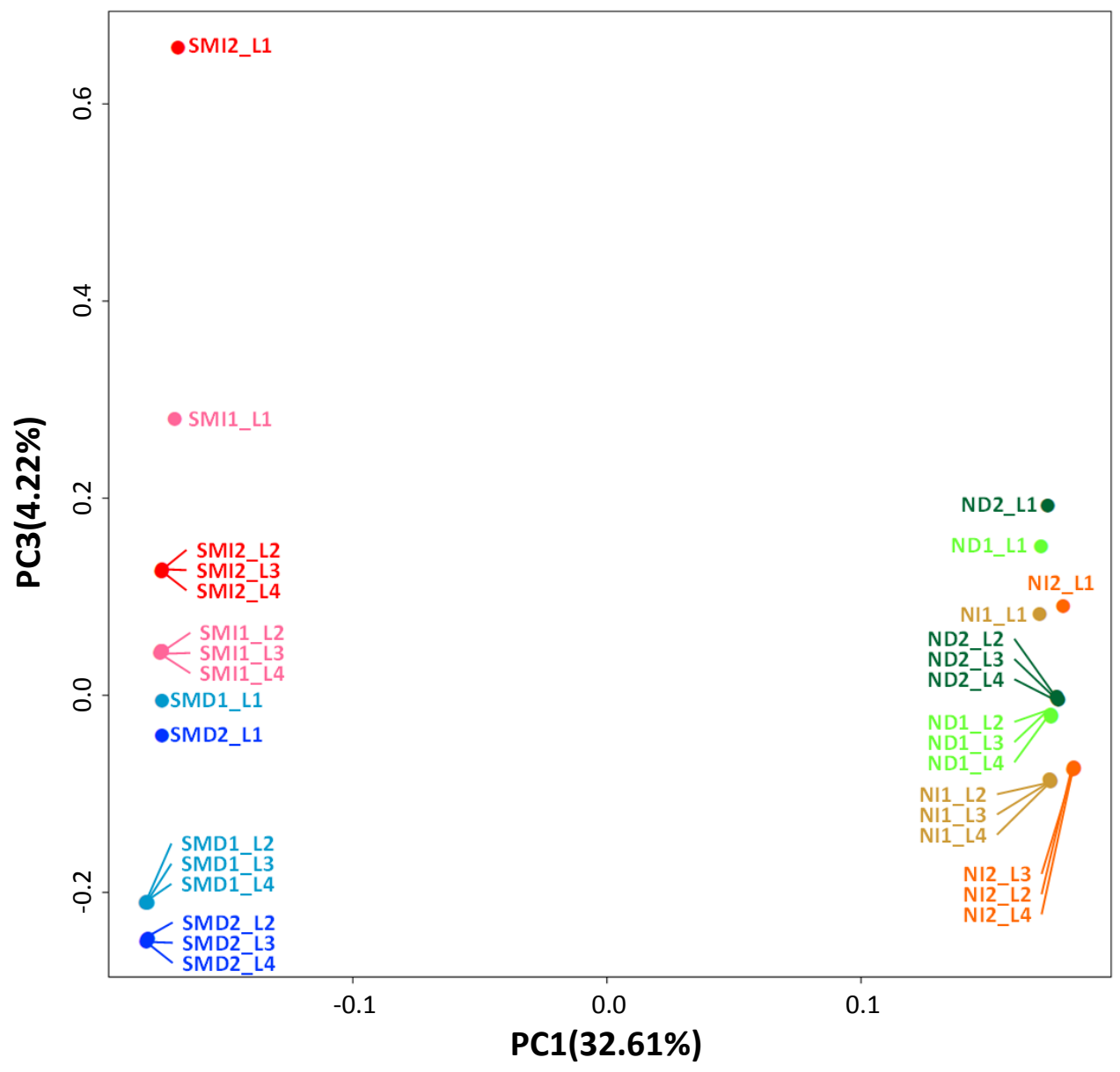




\section{Supplementary Table S2}

Putative functions of the predicted genes located in a 120-kb window centered on the 31 outlier loci on the Globodera pallida genome assembly version Gpal.v1.0 (Cotton et al. 2014). Relevant results of the BLAST search of the predicted genes against the annotated $G$. rostochiensis genome version nGr.v1.0 (Eves-van den Akker et al. 2016) are also shown. *: outlier SNP located in the gene, **: outlier SNP located in the exon.

\begin{tabular}{|c|c|c|c|c|c|c|c|}
\hline \multirow{2}{*}{ 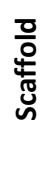 } & \multirow{2}{*}{$\begin{array}{l}\text { Outlier } \\
\text { locus }\end{array}$} & \multicolumn{4}{|c|}{ Globodera pallida genome } & \multicolumn{2}{|c|}{ BLAST against Globodera rostochiensis genome } \\
\hline & & Gene ID & $\begin{array}{l}\text { Location on } \\
\text { the scaffold }\end{array}$ & Putative gene function & $\begin{array}{l}\text { Peptide } \\
\text { signal }\end{array}$ & Gene ID & Putative gene function \\
\hline \multirow{13}{*}{4} & \multirow{13}{*}{$\begin{array}{c}\mathrm{SNP}_{-} \\
4_{-} \\
429075\end{array}$} & $\begin{array}{l}\begin{array}{l}\text { GPLIN_0000 } \\
30900\end{array} \\
\end{array}$ & 367074-371195 & actin protein 6 & no & $\underset{8}{\text { GROS_g1220 }}$ & spliceosome \\
\hline & & $\begin{array}{l}\text { GPLIN_0000 } \\
\quad 31000\end{array}$ & $371242-372608$ & nuclear Pore complex protein family member & no & & \\
\hline & & $\begin{array}{l}\text { GPLIN_0000 } \\
\quad 31100\end{array}$ & $398790-400048$ & transcription initiation factor TFIID subunit & no & & \\
\hline & & $\begin{array}{l}\text { GPLIN_0000 } \\
\quad 31200\end{array}$ & $403834-404255$ & beta 14 endoglucanase & no & & \\
\hline & & $\begin{array}{l}\text { GPLIN_0000 } \\
\text { 31300* }\end{array}$ & $428992-438734$ & transcribed hypothetical protein & no & $\underset{1}{\text { GROS_g0534 }}$ & $\begin{array}{l}\text { magnesium ion transport; sodium ion transmembrane } \\
\text { transport; integral to plasma membrane; cation channel } \\
\text { activity }\end{array}$ \\
\hline & & $\begin{array}{l}\text { GPLIN_0000 } \\
\quad 31400\end{array}$ & $439019-440137$ & transcribed hypothetical protein & no & & \\
\hline & & $\begin{array}{l}\text { GPLIN_0000 } \\
\quad 31500\end{array}$ & $441856-451123$ & cysteine synthase & no & & \\
\hline & & $\begin{array}{l}\text { GPLIN_0000 } \\
\quad 31600\end{array}$ & $457740-458980$ & long chain fatty acid transport protein 4 & no & $\underset{3}{\text { GROS_g1336 }}$ & fatty acid transport proteins \\
\hline & & $\begin{array}{l}\text { GPLIN_0000 } \\
\quad 31700\end{array}$ & $460388-460633$ & transcribed hypothetical protein & no & & \\
\hline & & $\begin{array}{l}\text { GPLIN_0000 } \\
\quad 31800\end{array}$ & $462978-464011$ & beta 1,3 galactosyltransferase 2 & no & $\underset{0}{\text { GROS_g0045 }}$ & galactosyltransferase \\
\hline & & $\begin{array}{l}\text { GPLIN_0000 } \\
\quad 31900\end{array}$ & $470256-470486$ & transcribed hypothetical protein & no & & \\
\hline & & $\begin{array}{l}\text { GPLIN_0000 } \\
\quad 32000\end{array}$ & $471353-473130$ & transcribed hypothetical protein & no & & \\
\hline & & $\begin{array}{l}\text { GPLIN_0000 } \\
32100\end{array}$ & $474046-474331$ & transcribed hypothetical protein & no & GROS_g1071 & $\begin{array}{l}\text { protein binding; stress-activated map kinase interacting } \\
\text { protein 1 (SIN1) }\end{array}$ \\
\hline
\end{tabular}




\begin{tabular}{|c|c|c|c|c|c|c|c|}
\hline \multirow{22}{*}{25} & \multirow{22}{*}{$\begin{array}{c}\mathrm{SNP}_{-} \\
25_{-} \\
304232\end{array}$} & $\begin{array}{l}\text { GPLIN_0001 } \\
49900\end{array}$ & $243326-245017$ & solute carrier family 35 member B1 & yes & GROS_g0215 & transport \\
\hline & & $\begin{array}{l}\text { GPLIN_0001 } \\
50000\end{array}$ & $245308-249627$ & mitogen activated protein kinase kinase kinase & no & $\underset{0}{\operatorname{GROS} \_0215}$ & MAPK signaling pathway \\
\hline & & $\begin{array}{l}\text { GPLIN_0001 } \\
\quad 50100\end{array}$ & 251276-252209 & superoxide dismutase (Cu Zn) & yes & $\underset{9}{\operatorname{GROS} \_g 0214}$ & peroxisome \\
\hline & & $\begin{array}{l}\text { GPLIN_0001 } \\
\quad 50200\end{array}$ & $252398-253488$ & transcribed hypothetical protein & no & $\underset{8}{\text { GROS_g0214 }}$ & transmembrane \\
\hline & & $\begin{array}{l}\text { GPLIN_0001 } \\
50300\end{array}$ & 254217-258092 & transcribed hypothetical protein & no & $\underset{6}{\operatorname{GROS} \_g 0214}$ & $\begin{array}{l}\text { RNA transport; negative regulation of DNA damage } \\
\text { checkpoint }\end{array}$ \\
\hline & & $\begin{array}{l}\text { GPLIN_0001 } \\
\quad 50400\end{array}$ & $258929-261360$ & T complex protein 1 subunit epsilon & no & $\underset{5}{\text { GROS_g0214 }}$ & $\begin{array}{l}\text { cytoskeleton organization; posttranslational protein } \\
\text { folding }\end{array}$ \\
\hline & & $\begin{array}{l}\text { GPLIN_0001 } \\
50500\end{array}$ & 261650-263494 & transcribed hypothetical protein & no & $\underset{2}{\text { GROS_g1428 }}$ & metabolism of xenobiotics by cytochrome P450 \\
\hline & & $\begin{array}{l}\text { GPLIN_0001 } \\
50600\end{array}$ & $263679-265256$ & protein vertebrate galectins & yes & $\underset{3}{\text { GROS_g0214 }}$ & galactose binding; signal transducer activity \\
\hline & & $\begin{array}{l}\text { GPLIN_0001 } \\
\quad 50700\end{array}$ & 265891-266885 & $\mathrm{N}$ alpha acetyltransferase 20 & no & $\underset{1}{\text { GROS_g0214 }}$ & endocytosis \\
\hline & & $\begin{array}{l}\text { GPLIN_0001 } \\
50800\end{array}$ & $266955-269813$ & transcribed hypothetical protein & no & $\underset{0}{\text { GROS_g0214 }}$ & protein homodimerization activity \\
\hline & & $\begin{array}{l}\text { GPLIN_0001 } \\
\quad 50900\end{array}$ & 269952-271262 & transcribed hypothetical protein & no & $\underset{9}{\operatorname{GROS} \_g 0213}$ & transmembrane \\
\hline & & $\begin{array}{l}\text { GPLIN_0001 } \\
51000\end{array}$ & $271403-272406$ & transcribed hypothetical protein & no & & \\
\hline & & $\begin{array}{l}\text { GPLIN_0001 } \\
\quad 51100\end{array}$ & $273509-275230$ & fasciculation and elongation protein zeta 2 & no & $\underset{7}{\text { GROS_g0213 }}$ & axon guidance \\
\hline & & $\begin{array}{l}\text { GPLIN_0001 } \\
\quad 51200\end{array}$ & $275973-277291$ & $\begin{array}{l}\text { protein kinase domain containing protein, ck worm } \\
\text { protein kinase }\end{array}$ & no & & \\
\hline & & $\begin{array}{l}\text { GPLIN_0001 } \\
\quad 51300\end{array}$ & 279494-280946 & calmodulin & no & $\underset{6}{\operatorname{GROS} \_ \text {g0213 }}$ & calmodulin \\
\hline & & $\begin{array}{l}\text { GPLIN_0001 } \\
\quad 51400\end{array}$ & 284171-284443 & transcribed hypothetical protein & no & & \\
\hline & & $\begin{array}{l}\text { GPLIN_0001 } \\
\quad 51500\end{array}$ & 299966-302277 & cyclin-dependent kinase inhibitor & no & & \\
\hline & & $\begin{array}{l}\text { GPLIN_0001 } \\
\text { 51600* }\end{array}$ & $303454-310418$ & exportin 7 & no & $\underset{1}{\operatorname{GROS} \_ \text {g0213 }}$ & $\begin{array}{l}\text { nuclear export signal receptor activity; protein export } \\
\text { from nucleus; nuclear pore }\end{array}$ \\
\hline & & $\begin{array}{l}\text { GPLIN_0001 } \\
\quad 51700\end{array}$ & $310648-311820$ & glutaredoxin 3 & no & $\underset{0}{\text { GROS_g0213 }}$ & glutaredoxin-3 \\
\hline & & $\begin{array}{l}\text { GPLIN_0001 } \\
51800\end{array}$ & 313085-314369 & transcribed hypothetical protein & no & & \\
\hline & & $\begin{array}{c}\text { GPLIN_0001 } \\
51900\end{array}$ & $315934-316953$ & transcribed hypothetical protein & no & $\underset{9}{\operatorname{GROS} \_ \text {_0212 }}$ & transmembrane \\
\hline & & $\begin{array}{c}\text { GPLIN_0001 } \\
52000\end{array}$ & $317223-324014$ & DEAD Box protein & no & $\begin{array}{c}\text { GROS_g0212 } \\
8\end{array}$ & ATP catabolic process \\
\hline
\end{tabular}




\begin{tabular}{|c|c|c|c|c|c|c|c|}
\hline & & $\begin{array}{c}\text { GPLIN_0001 } \\
52100\end{array}$ & $328566-329000$ & transcribed hypothetical protein & no & & \\
\hline & & $\begin{array}{l}\text { GPLIN_0001 } \\
52200\end{array}$ & 329118-330907 & transcribed hypothetical protein & no & $\underset{6}{\text { GROS_g0212 }}$ & chromatin binding \\
\hline & & $\begin{array}{l}\text { GPLIN_0001 } \\
\quad 52300\end{array}$ & 335501-336396 & immunoglobulin i set domain containing protein & yes & GROS_g0212 & transmembrane \\
\hline & & $\begin{array}{l}\text { GPLIN_0001 } \\
52400\end{array}$ & $336805-340764$ & transcribed hypothetical protein & no & $\begin{array}{c}\text { GROS_g0212 } \\
4\end{array}$ & Golgi apparatus \\
\hline & & $\begin{array}{l}\text { GPLIN_0001 } \\
52500\end{array}$ & $341193-341716$ & transcribed hypothetical protein & no & & \\
\hline \multirow{17}{*}{44} & \multirow{12}{*}{$\begin{array}{c}\mathrm{SNP}_{-} \\
44_{-} \\
221212\end{array}$} & $\begin{array}{l}\text { GPLIN_0002 } \\
32300\end{array}$ & 163392-163732 & transcribed hypothetical protein & no & & \\
\hline & & $\begin{array}{l}\text { GPLIN_0002 } \\
\quad 32400\end{array}$ & 168518-169562 & transcribed hypothetical protein & yes & $\underset{5}{\text { GROS_g0408 }}$ & signal peptide \\
\hline & & $\begin{array}{c}\text { GPLIN_0002 } \\
32500\end{array}$ & 169991-170378 & transcribed hypothetical protein & no & & \\
\hline & & $\begin{array}{l}\text { GPLIN_0002 } \\
32600\end{array}$ & 171849-174837 & transcribed hypothetical protein & yes & $\underset{7}{\text { GROS_g0408 }}$ & signal peptide \\
\hline & & $\begin{array}{c}\text { GPLIN_0002 } \\
32700\end{array}$ & $180474-181761$ & phosphatidylcholine:ceramide & no & $\begin{array}{c}\text { GROS_g0408 } \\
9\end{array}$ & sphingolipid metabolism \\
\hline & & $\begin{array}{l}\text { GPLIN_0002 } \\
\quad 32800\end{array}$ & $183265-184828$ & $60 S$ ribosomal protein $L 4$ & no & $\underset{0}{\text { GROS_g0409 }}$ & cell wall modification; ribosomal protein L1e signature \\
\hline & & $\begin{array}{c}\text { GPLIN_0002 } \\
32900\end{array}$ & 184937-188002 & palmitoyltransferase ZDHHC2 & no & $\begin{array}{c}\text { GROS_g0409 } \\
1\end{array}$ & proteinS-acyltransferase \\
\hline & & $\begin{array}{l}\text { GPLIN_0002 } \\
\quad 33000\end{array}$ & 196131-198830 & transcribed hypothetical protein & no & $\underset{9}{\text { GROS_g1153 }}$ & Transmembrane \\
\hline & & $\begin{array}{c}\text { GPLIN_0002 } \\
33100\end{array}$ & 198931-200169 & transcribed hypothetical protein & no & & \\
\hline & & $\begin{array}{c}\text { GPLIN_0002 } \\
33200\end{array}$ & $200212-201447$ & transcribed hypothetical protein & no & & \\
\hline & & $\begin{array}{l}\text { GPLIN_0002 } \\
\quad 33300\end{array}$ & 201499-202356 & transcribed hypothetical protein & no & & \\
\hline & & $\begin{array}{l}\text { GPLIN_0002 } \\
\quad 33400\end{array}$ & 202494-203706 & transcribed hypothetical protein & no & & \\
\hline & \multirow{5}{*}{$\begin{array}{c}\mathrm{SNP}_{-} \\
44_{-} \\
221214\end{array}$} & $\begin{array}{l}\text { GPLIN_0002 } \\
\quad 33500\end{array}$ & 203859-205030 & worm specific Argonaute NRDE 3 & no & & \\
\hline & & $\begin{array}{l}\text { GPLIN_0002 } \\
\quad 33600\end{array}$ & 205120-205935 & $\begin{array}{l}\text { transcription factor TFIID, C-terminal DNA glycosylase, N- } \\
\text { terminal }\end{array}$ & no & & \\
\hline & & $\begin{array}{l}\text { GPLIN_0002 } \\
\quad 33700\end{array}$ & 206066-211386 & transcribed hypothetical protein & no & & \\
\hline & & $\begin{array}{l}\text { GPLIN_0002 } \\
\quad 33800\end{array}$ & 211708-212533 & transcribed hypothetical protein & no & & \\
\hline & & $\begin{array}{l}\text { GPLIN_0002 } \\
\quad 33900\end{array}$ & 212735-214448 & transcribed hypothetical protein & no & & \\
\hline
\end{tabular}


GPLIN_0002 221431-221718 transcribed hypothetical protein

transcribed hypothetical protein

34100

221849-222821 polynucleotide kinase 3' phosphatase

GPLIN_0002

34200

255627-261288 macrophage erythroblast attacher

GPLIN_0002 264876-267441 mitochondrial processing peptidase beta subunit

GPLIN_0002

34400

34500

GPLIN_0002 34600

GPLIN_0002 34700

GPLIN_0002

34800

GPLIN 0002 34900

277860-282940 4 aminobutyrate aminotransferase, mitochondrial

GPLIN_0003

1-3999 transcribed hypothetical protein

GPLIN_0003

11500

GPLIN_0003

11600

19418-20911 transcribed hypothetical protein

30359-32404 transcribed hypothetical protein

SNP_ GPLIN_0003

66_ 11700

55507 GPLIN_0003

36477-37252 transcribed hypothetical protein

45302-45915 transcribed hypothetical protein

46907-48176 BTB:POZ domain containing protein 3

SNP_ $\quad 11900$

$\begin{array}{cc}66 & \text { GPLIN_0003 } \\ 131126 & 12000\end{array}$

12000

12100

49696-50448 transcribed hypothetical protein

GPLIN 0003

12200

53144-55475 protein containing SPRY domain

12300 no

no

yes

no

no

no

no

ROS_g0323

GROS_g0323 beta-Alanine metabolism / beta-Alanine metabolism

GROS_g1278 signal peptide

GROS_g1426 RBP-4 protein [G. pallida]

GROS_g1419 RBP-4 protein [G. pallida]; secreted SPRY domain-

6 containing protein 18 [G. rostochiensis]

no

GROS_g0402 riboflavin metabolism

GROS_g1412 RBP-1 protein, partial [G. pallida]

GROS_g1413

6

RBP-4 protein [G. pallida]; transmembrane

GROS_g1427 RBP-1 protein [G. pallida]

GROS_g1118 peptidase family M41

GROS_g1413 truncated secreted SPRY domain-containing protein 15 , partial [G. rostochiensis]; signal peptide 


\begin{tabular}{|c|c|c|c|c|c|c|c|}
\hline & & $\begin{array}{c}\text { GPLIN_0003 } \\
12400\end{array}$ & $71724-72660$ & transcribed hypothetical protein & no & & \\
\hline & & $\begin{array}{l}\text { GPLIN_0003 } \\
12500\end{array}$ & 92978-94740 & protein containing SPRY domain & no & $\underset{8}{\text { GROS_g1427 }}$ & RBP-1 protein [G. pallida] \\
\hline & & $\begin{array}{l}\text { GPLIN_0003 } \\
12600\end{array}$ & 95754-96913 & protein containing SPRY domain & no & $\underset{7}{\operatorname{GROS} g 1428}$ & $\begin{array}{l}\text { truncated secreted SPRY domain-containing protein } 15, \\
\text { partial [G. rostochiensis] }\end{array}$ \\
\hline & & $\begin{array}{l}\text { GPLIN_0003 } \\
12700\end{array}$ & 107749-107949 & EF-hand 2 domain containing protein & no & $\underset{1}{\text { GROS_g1428 }}$ & EF-hand calcium-binding domain. \\
\hline & & $\begin{array}{c}\text { GPLIN_0003 } \\
12800\end{array}$ & 111831-112806 & transcribed hypothetical protein & no & $\begin{array}{c}\text { GROS_g0572 } \\
9\end{array}$ & protein SAX-7; transmembrane \\
\hline & & $\begin{array}{l}\text { GPLIN_0003 } \\
12900\end{array}$ & $112920-115358$ & group 1 glycosyl transferase & no & $\underset{7}{\operatorname{GROS} \_ \text {g0172 }}$ & glycosyl transferases group 1 \\
\hline & & $\begin{array}{c}\text { GPLIN_0003 } \\
13000\end{array}$ & 119091-120888 & transcribed hypothetical protein & no & & \\
\hline & & $\begin{array}{c}\text { GPLIN_0003 } \\
13100\end{array}$ & $124022-124830$ & transcribed hypothetical protein & no & & \\
\hline & & GPLIN_0003 & & & & & \\
\hline & & $\begin{array}{c}13200 * \\
\text { (SNP_66_13 } \\
1126)\end{array}$ & 129063-137156 & Sensory AXon guidance family member (sax 7) & no & $\underset{9}{\text { GROS_g0572 }}$ & protein SAX-7; sensory AXon guidance ; transmembrane \\
\hline & & $\begin{array}{l}\text { GPLIN_0003 } \\
13300\end{array}$ & 139135-140624 & transcribed hypothetical protein & no & & \\
\hline & & $\begin{array}{l}\text { GPLIN_0003 } \\
13400\end{array}$ & 142713-144269 & transcribed hypothetical protein & no & & \\
\hline & & $\begin{array}{l}\text { GPLIN_0003 } \\
13500\end{array}$ & $145772-146732$ & transcribed hypothetical protein & no & $\underset{6}{\operatorname{GROS} g 1327}$ & signal peptide \\
\hline & & $\begin{array}{l}\text { GPLIN_0003 } \\
13600\end{array}$ & 154523-157608 & $\begin{array}{l}\text { beta } 1,4 \text { endoglucanase (cell wall modifying protein); } \\
\text { putative GH5 cellulase (cellulose degradation) }\end{array}$ & yes & $\underset{6}{\operatorname{GROS} \_g 0744}$ & beta-1,4-endoglucanase, partial; cellulase \\
\hline & & $\begin{array}{l}\text { GPLIN_0003 } \\
13700\end{array}$ & 158653-160495 & transcribed hypothetical protein & no & $\underset{5}{\text { GROS_g0210 }}$ & $\begin{array}{l}\text { poly }(A) \text { polymerase central domain; nuclear mRNA } \\
\text { splicing, via spliceosome }\end{array}$ \\
\hline & & $\begin{array}{l}\text { GPLIN_0003 } \\
13800\end{array}$ & 167056-168124 & transcribed hypothetical protein & no & $\underset{7}{\operatorname{GROS} \_g 0744}$ & EB module \\
\hline & & $\begin{array}{l}\text { GPLIN_0003 } \\
13900\end{array}$ & 168962-169322 & transcribed hypothetical protein & no & $\underset{6}{\operatorname{GROS} \text { _g0112 }}$ & transmembrane \\
\hline & & $\begin{array}{c}\text { GPLIN_0003 } \\
14000\end{array}$ & $183685-184563$ & $\begin{array}{l}\text { transcribed hypothetical protein, similar to } G \text {. } \\
\text { rostochiensis effector } 1106\end{array}$ & yes & $\begin{array}{c}\text { GROS_g1430 } \\
9\end{array}$ & signal peptide; 1106 effector family [G. rostochiensis] \\
\hline & $85_{-}$ & $\begin{array}{l}\text { GPLIN_0003 } \\
82000\end{array}$ & 67804-68769 & glutaminyl peptide cyclotransferase & no & $\underset{4}{\text { GROS_g0737 }}$ & $\begin{array}{l}\text { signal peptide; peptidase M28 domain containing protein } \\
\text { [Haemonchus contortus] }\end{array}$ \\
\hline & 126066 & $\begin{array}{l}\text { GPLIN_0003 } \\
\quad 82100\end{array}$ & 84608-86814 & transcribed hypothetical protein & no & $\underset{4}{\text { GROS_g1412 }}$ & RBP-4 protein [G. pallida] \\
\hline 85 & SNP & $\begin{array}{l}\text { GPLIN_0003 } \\
82200\end{array}$ & $94832-100930$ & zinc finger protein & no & $\underset{6}{\text { GROS_g1133 }}$ & zinc finger protein [Loa loa] \\
\hline & $\begin{array}{c}85 \\
126206\end{array}$ & $\begin{array}{l}\text { GPLIN_0003 } \\
\quad 82300\end{array}$ & 110433-110747 & transcribed hypothetical protein & no & & \\
\hline
\end{tabular}




\begin{tabular}{|c|c|c|c|c|c|c|c|}
\hline & & $\begin{array}{l}\text { GPLIN_0003 } \\
\quad 82400\end{array}$ & $120748-122590$ & BTB:POZ domain containing protein 3 & no & $\underset{3}{\text { GROS_g1419 }}$ & $\begin{array}{l}\text { truncated secreted SPRY domain-containing protein } 15, \\
\text { partial [G. rostochiensis] }\end{array}$ \\
\hline & & $\begin{array}{l}\text { GPLIN_0003 } \\
\quad 82500\end{array}$ & $126792-129853$ & SPla RYanodine receptor SPRY & no & $\underset{3}{\text { GROS_g1416 }}$ & RBP-4 protein [G. pallida] \\
\hline & & $\begin{array}{l}\text { GPLIN_0003 } \\
\quad 82600\end{array}$ & $142203-143446$ & transcribed hypothetical protein & no & & \\
\hline & & $\begin{array}{l}\text { GPLIN_0003 } \\
\quad 82700\end{array}$ & 143942-144891 & transcribed hypothetical protein & no & & \\
\hline & & $\begin{array}{l}\text { GPLIN_0003 } \\
\quad 82800\end{array}$ & 151467-154962 & E9 protein & no & $\begin{array}{c}\text { GROS_g1412 } \\
3 \\
\text { GROS_g0539 }\end{array}$ & signal peptide \\
\hline & & $\begin{array}{l}\text { GPLIN_0003 } \\
\quad 82900\end{array}$ & 164278-168506 & glutathione synthetase & no & GROS_g1379 & $\begin{array}{l}\text { glutathione synthetase-like [Maylandia zebra] / } \\
\text { glutathionesynthase; signal peptide }\end{array}$ \\
\hline & & $\begin{array}{l}\text { GPLIN_0003 } \\
\quad 83000\end{array}$ & 169444-172268 & Guanine nucleotide binding protein $\mathrm{G}(\mathrm{o})$ subunit & no & $\begin{array}{l}\text { GROS_g0538 } \\
9\end{array}$ & $\begin{array}{l}\text { guanine nucleotide-binding protein alpha-3 subunit } \\
\text { [Brugia malayi] }\end{array}$ \\
\hline & & $\begin{array}{l}\text { GPLIN_0003 } \\
\quad 83100\end{array}$ & 174565-177704 & ODR 3 & no & $\begin{array}{l}\text { GROS_g0538 } \\
9\end{array}$ & $\begin{array}{l}\text { guanine nucleotide-binding protein alpha-3 subunit [B. } \\
\text { malayi] }\end{array}$ \\
\hline & & $\begin{array}{l}\text { GPLIN_0003 } \\
83200\end{array}$ & 179602-190327 & guanine nucleotide exchange factor for Ras & no & $\begin{array}{l}\text { GROS_g0538 } \\
8\end{array}$ & regulation of Ral GTPase activity \\
\hline \multirow{11}{*}{111} & \multirow{11}{*}{$\begin{array}{c}\text { SNP_111_- } \\
140151\end{array}$} & $\begin{array}{l}\text { GPLIN_0004 } \\
50000\end{array}$ & 79896-81897 & UDP glucuronosyltransferase & yes & GROS_g0933 & integral to plasma membrane \\
\hline & & $\begin{array}{l}\text { GPLIN_0004 } \\
\quad 50100\end{array}$ & $94652-95140$ & hypothetical protein & no & & \\
\hline & & $\begin{array}{l}\text { GPLIN_0004 } \\
\quad 50200\end{array}$ & 98715-99013 & transcribed hypothetical protein & no & & \\
\hline & & $\begin{array}{l}\text { GPLIN_0004 } \\
50300\end{array}$ & 120569-121060 & hypothetical protein & no & & \\
\hline & & $\begin{array}{l}\text { GPLIN_0004 } \\
50400\end{array}$ & 126241-129974 & protein containing SPRY domain & no & $\underset{5}{\text { GROS_g1419 }}$ & $\begin{array}{l}\text { dendrite morphogenesis, truncated secreted SPRY } \\
\text { domain-containing protein 15, partial [G. rostochiensis] }\end{array}$ \\
\hline & & $\begin{array}{l}\text { GPLIN_0004 } \\
50500\end{array}$ & $132676-135723$ & inversin protein alternative, ankyrin repeat protein & no & $\underset{2}{\text { GROS_g1419 }}$ & protein binding \\
\hline & & $\begin{array}{l}\text { GPLIN_0004 } \\
\quad 50600\end{array}$ & 133821-134846 & BTB:POZ domain containing protein 3 & no & $\underset{5}{\text { GROS_g1419 }}$ & $\begin{array}{l}\text { dendrite morphogenesis, truncated secreted SPRY } \\
\text { domain-containing protein } 15 \text {, partial [G. rostochiensis] }\end{array}$ \\
\hline & & $\begin{array}{l}\text { GPLIN_0004 } \\
\quad 50700\end{array}$ & 138326-138779 & transcribed hypothetical protein & no & & \\
\hline & & $\begin{array}{l}\text { GPLIN_0004 } \\
\quad 50800\end{array}$ & 138941-139562 & Nematode AStacin protease family member & no & $\begin{array}{c}\text { GROS_g0742 } \\
2 \\
\text { GROS_g1280 }\end{array}$ & molting cycle, collagen and cuticulin-based cuticle; Astacin \\
\hline & & $\begin{array}{l}\text { GPLIN_0004 } \\
\quad 50900\end{array}$ & 144927-150255 & NAD kinase domain containing protein 1 & no & $\begin{array}{c}7 / \\
\text { GROS_g1280 } \\
8\end{array}$ & NAD metabolic process / mRNA surveillance pathway \\
\hline & & $\begin{array}{l}\text { GPLIN_0004 } \\
51000\end{array}$ & 153798-155515 & transcribed hypothetical protein & no & & \\
\hline
\end{tabular}




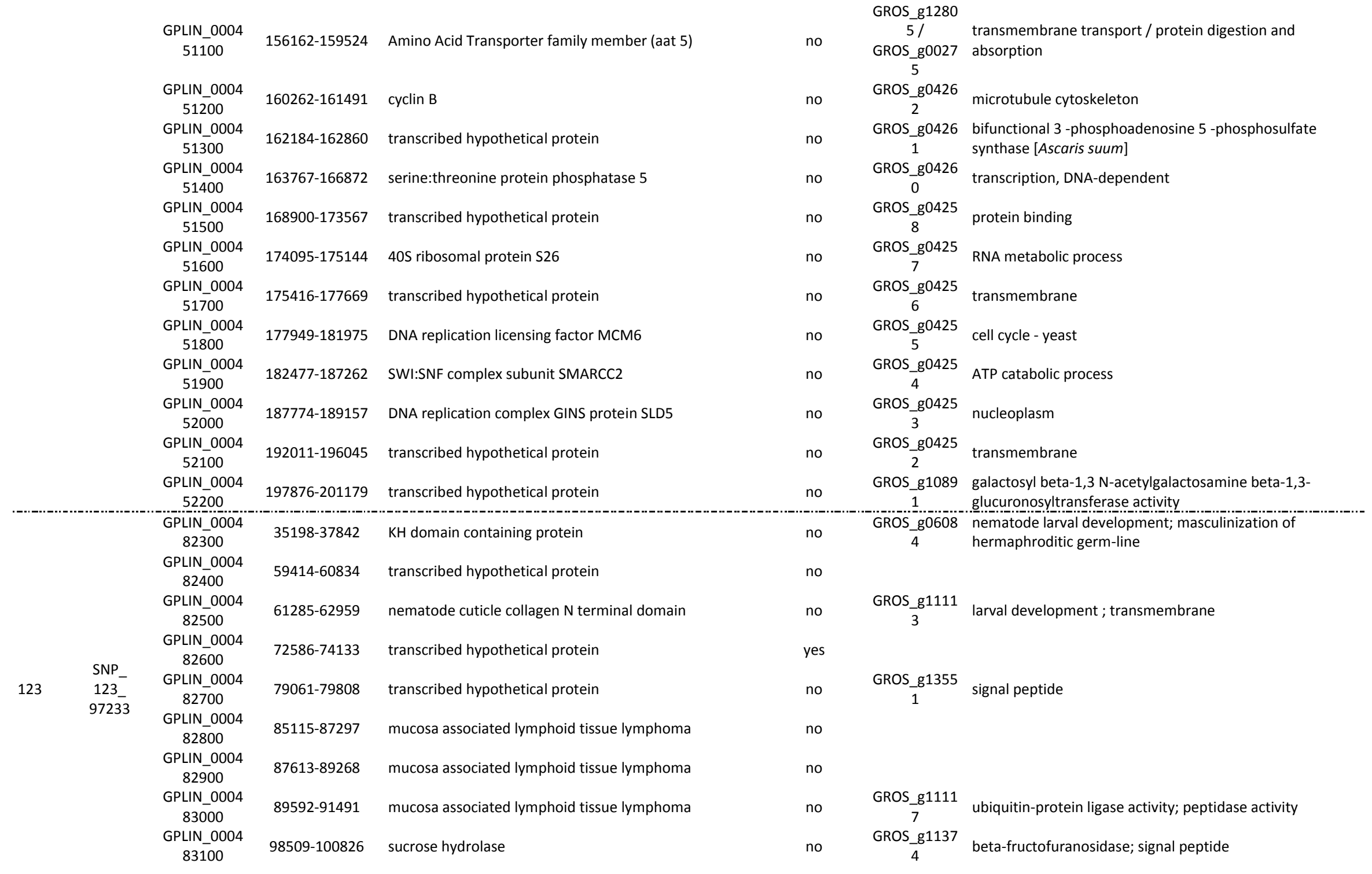


GPLIN_0004 101689-102752 tail length tape measure protein

103018-107209 beta fructofuranosidase; secreted GH32 fructosidase

GPLIN 0004

83400

GPLIN_0004

83500

112509-112790 transcribed hypothetical protein

GPLIN_0004

83600

GPLIN_0004

83700

GPLIN_0004

PLIN_0004

GPLIN_0004

84000

GPLIN_0004

84100

GPLIN_0004

GPLIN_0004

GPLIN_0004

84400

84500

GPLIN_0004

GPLIN_0006

GLIN_0006

26600

26700

182

GPLIN_0006

SNP_ $\quad 26800$

26900

27000
108777-111065 transcribed hypothetical protein

117038-117476 transcribed hypothetical protein

119298-120112 mps one binder kinase activator 3 like

120304-121636 ubiquitin interacting motif

121782-123696 ATP synthase subunit beta, mitochondrial

123896-127752 protein arginine $\mathrm{N}$ methyltransferase 5

155919-159554 mitotic checkpoint serine:threonine protein

$1034-2234$

protein containing SPRY domain

4596-5610

9510-11116 protein containing SPRY domain

13854-21499 protein containing SPRY domain

23491-25804 protein containing SPRY domain

no
GROS_g1139 beta-fructofuranosidase; plant-type cell wall modification

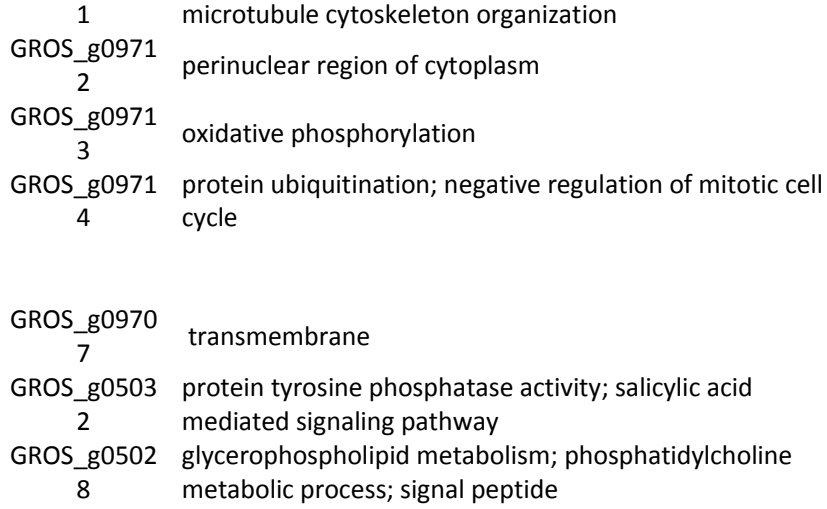

GROS_g0428 regulation of chromosome segregation; positive regulation 7 of intrinsic apoptotic signaling pathway / mitotic cell cycle GROS_g0502 spindle assembly checkpoint

GROS_g1424 regulation of Ran GTPase activity; RBP-1 protein
$1 \quad$ [G.pallida]

GROS g1418 regulation of Ran GTPase activity; RBP-4 protein [G. 4 pallida]

GROS_g1419 cytoplasmic microtubule; RBP-4 protein [G. pallida]

GROS_g1419 truncated secreted SPRY domain-containing protein 15,

5 partial [G. rostochiensis] 


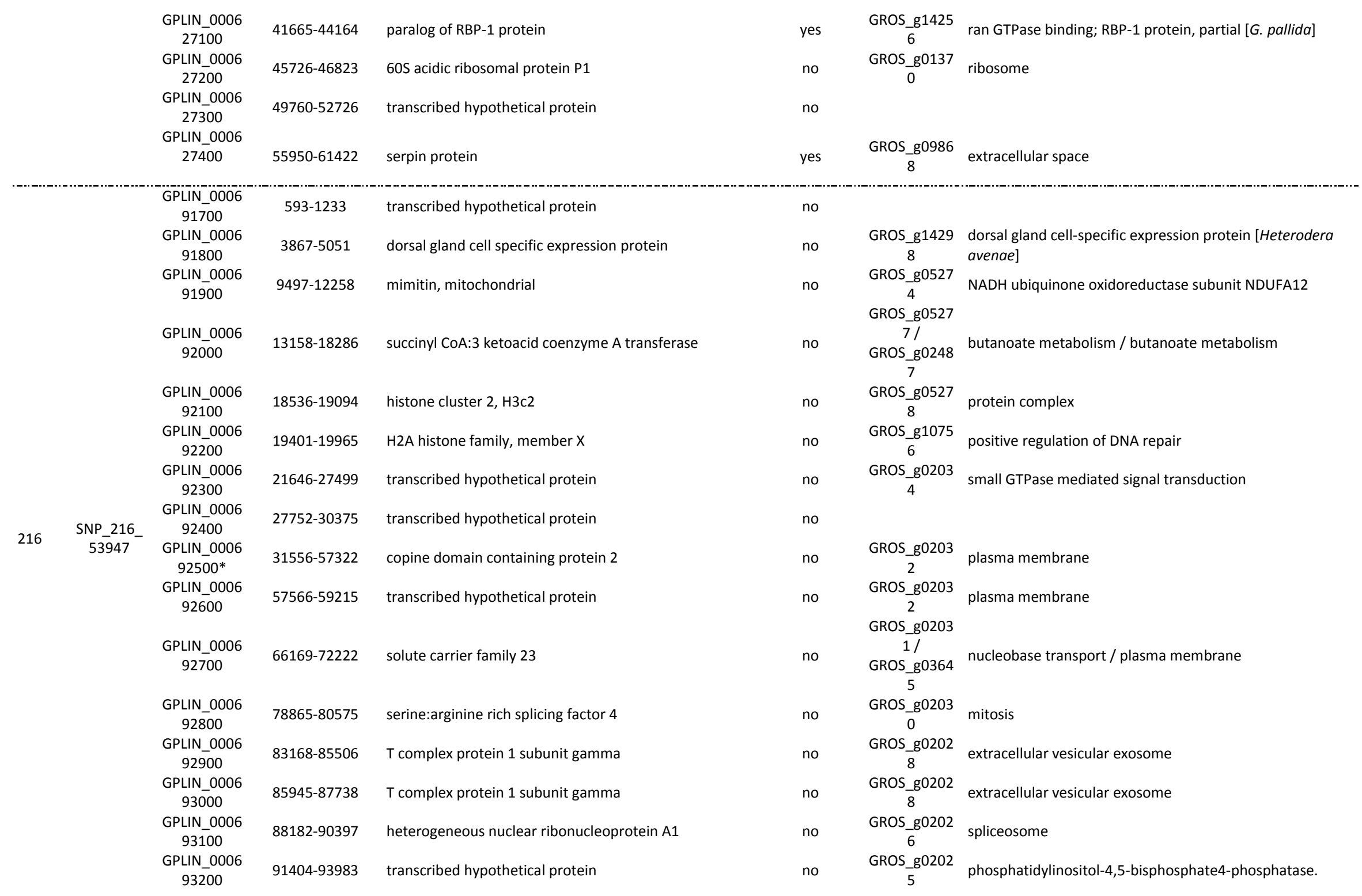




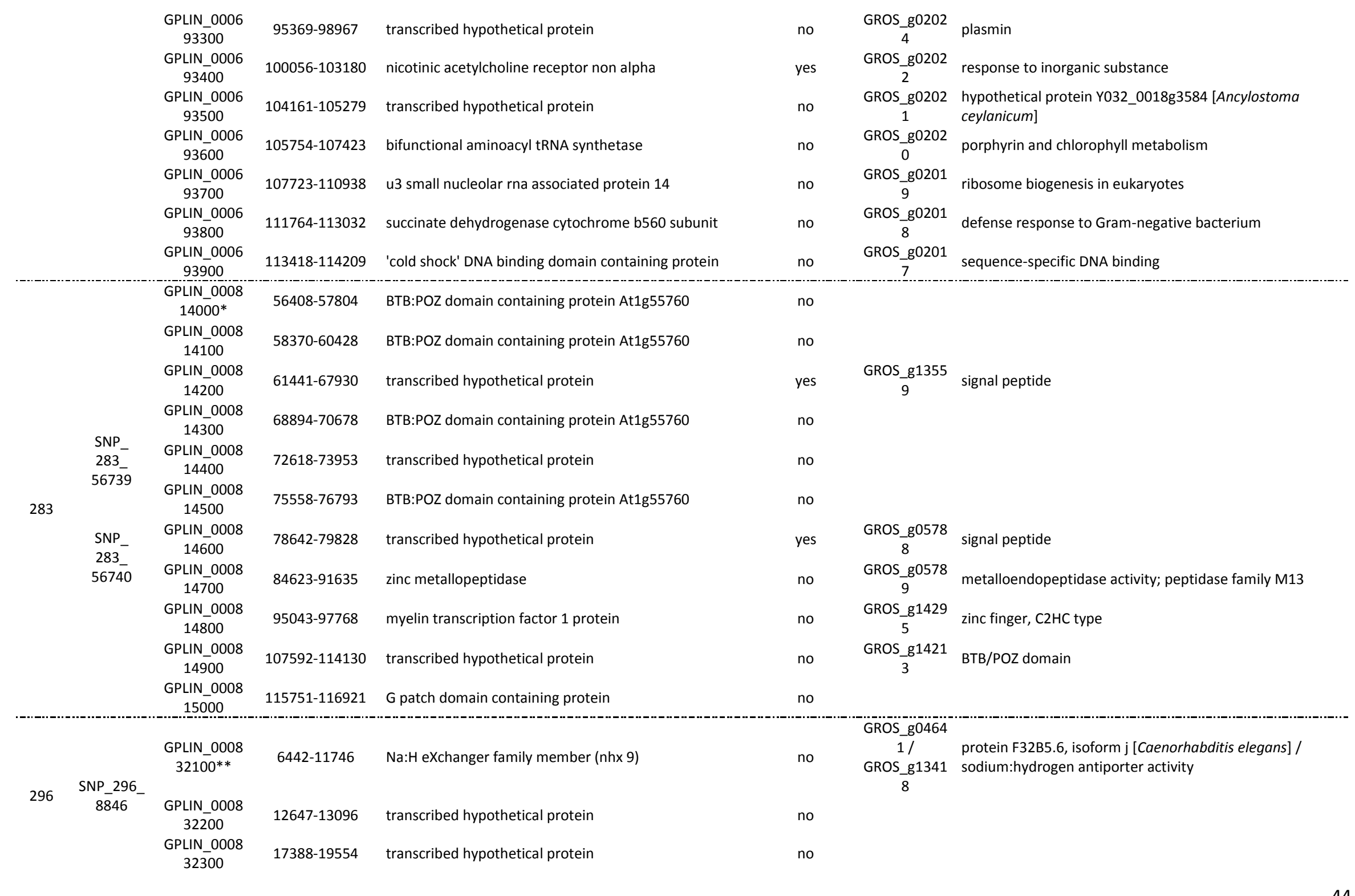




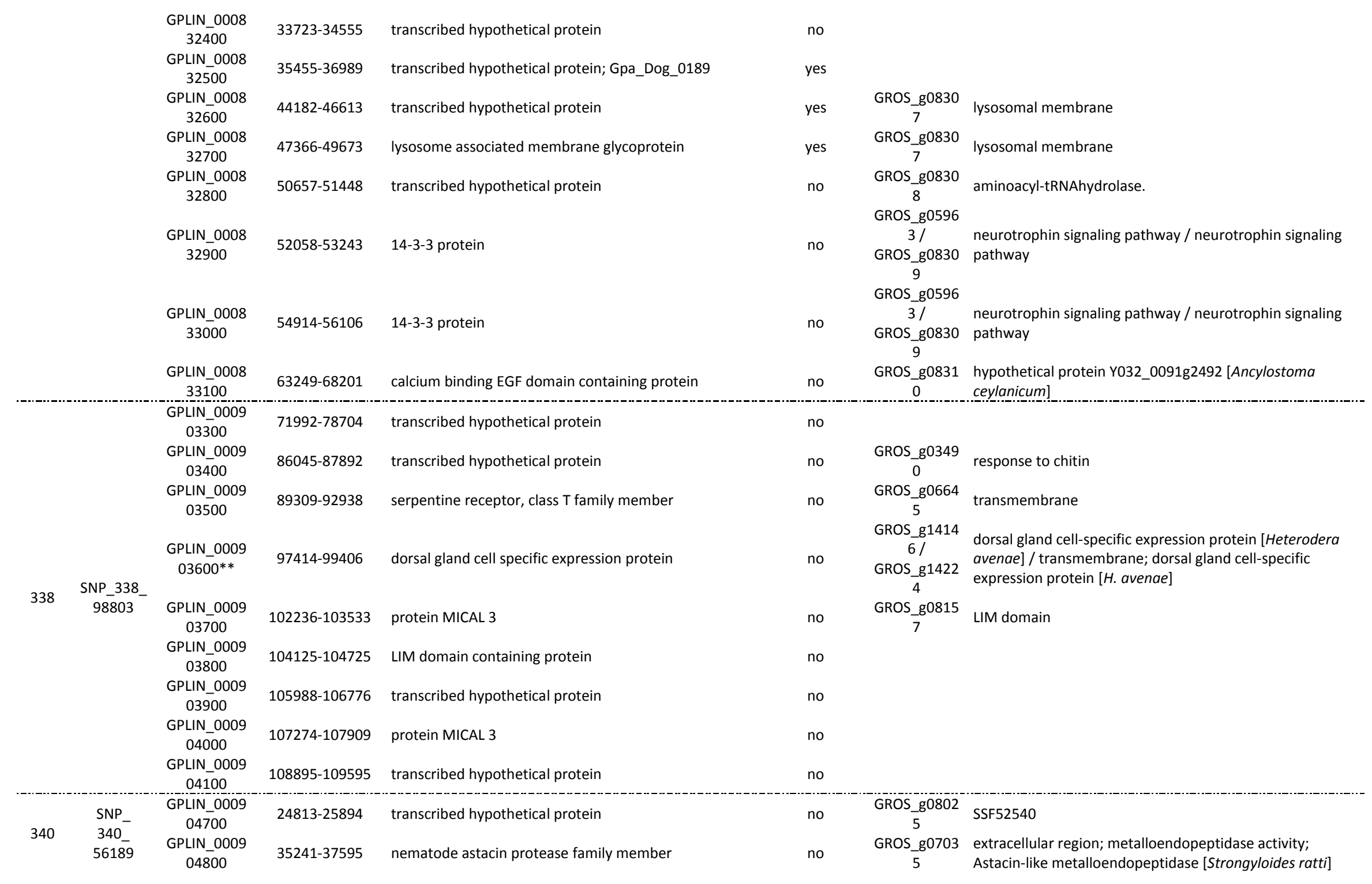




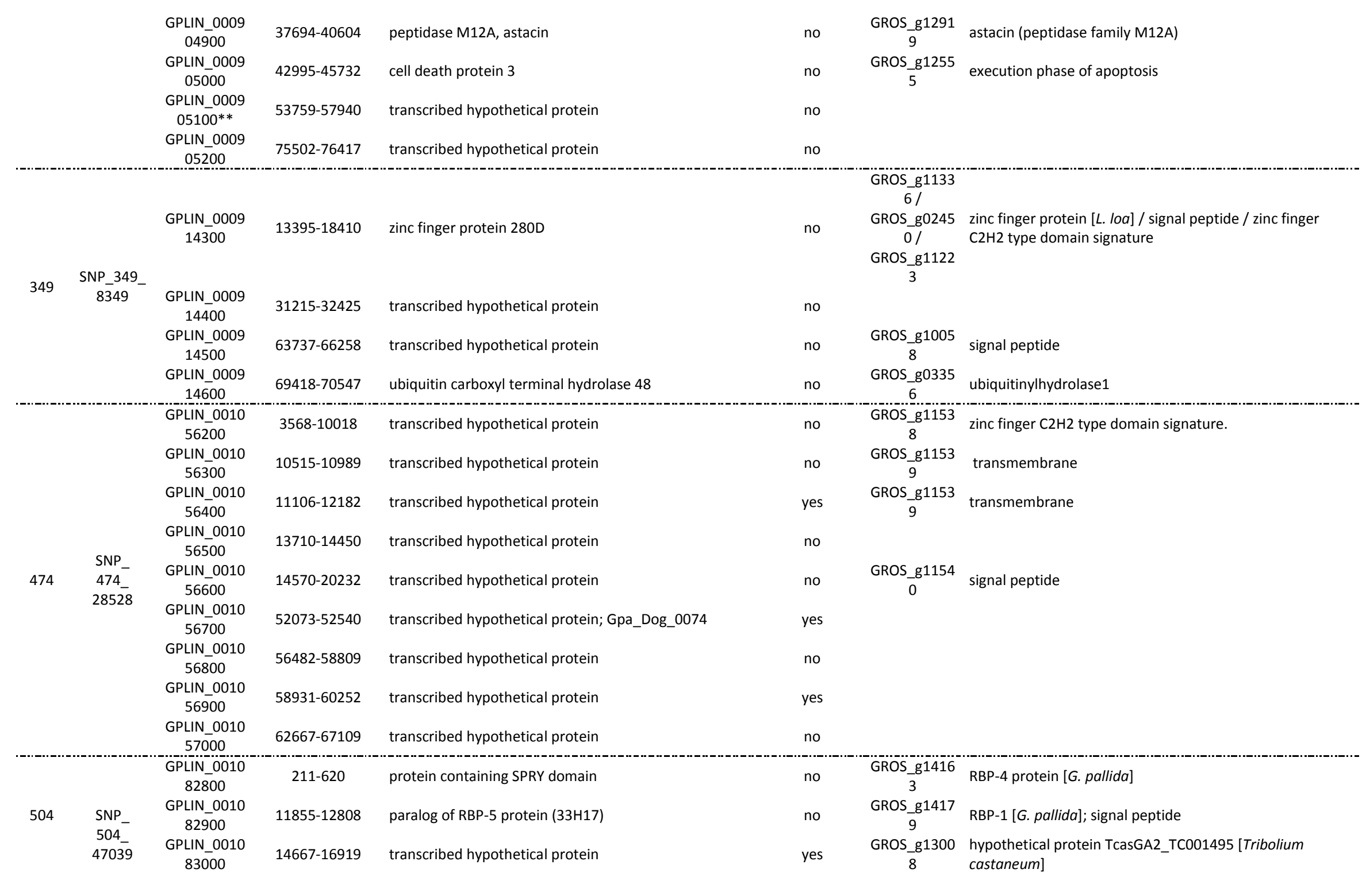




\begin{tabular}{|c|c|c|c|c|c|c|c|}
\hline & & $\begin{array}{c}\text { GPLIN_0010 } \\
83100\end{array}$ & $18255-23950$ & transcribed hypothetical protein & yes & \multirow[t]{2}{*}{$\underset{6}{\operatorname{GROS} \_ \text {g1045 }}$} & \multirow{2}{*}{$\begin{array}{l}\text { thap domain-containing protein } 4[\text { A. suum]; } \\
\text { transmembrane }\end{array}$} \\
\hline & & $\begin{array}{c}\text { GPLIN_0010 } \\
83200\end{array}$ & $25548-26905$ & transcribed hypothetical protein & no & & \\
\hline & & $\begin{array}{l}\text { GPLIN_0010 } \\
\quad 83300\end{array}$ & $32640-39130$ & serine:threonine protein kinase SIK3 & no & GROS_g1045 & serine threonine-protein kinase kin-29 [A. suum] \\
\hline & & $\begin{array}{l}\text { GPLIN_0010 } \\
\text { 83400* }\end{array}$ & 43996-50149 & 3 hydroxy 3 methylglutaryl coenzyme A reductase & no & $\underset{2}{\text { GROS_g1045 }}$ & $\begin{array}{l}\text { hmg CoA reductase A [Polysphondylium pallidum PN500]; } \\
\text { protein homodimerization activity }\end{array}$ \\
\hline & & $\begin{array}{l}\text { GPLIN_0010 } \\
83500\end{array}$ & $54107-59069$ & transcribed hypothetical protein & no & GROS_g1045 & $\begin{array}{l}\text { peptidase M10A M12B domain containing protein }[\mathrm{H} . \\
\text { contortus]; transmembrane; matrixin }\end{array}$ \\
\hline \multirow{6}{*}{782} & \multirow{6}{*}{$\begin{array}{c}\text { SNP }_{-} \\
782_{-} \\
20136\end{array}$} & $\begin{array}{l}\text { GPLIN_0012 } \\
57900\end{array}$ & 8259-9831 & transcribed hypothetical protein & no & GROS_g1414 & $\begin{array}{l}\text { dorsal gland cell-specific expression protein }[\mathrm{H} \text {. avenae }] \\
\text { putative esophageal gland cell protein } \mathrm{Hgg}-20[\mathrm{H} \text {. glycines }]\end{array}$ \\
\hline & & $\begin{array}{l}\text { GPLIN_0012 } \\
58000\end{array}$ & $16237-17191$ & transcribed hypothetical protein & no & GROS_g1421 & BTB/POZ domain \\
\hline & & $\begin{array}{l}\text { GPLIN_0012 } \\
58100^{* *}\end{array}$ & $19137-20558$ & paralog of RBP-1 protein; Gpa_Dog_0077 & yes & GROS_g1423 & $\begin{array}{l}\text { RBP-1 protein [G. pallida]; secreted SPRY domain- } \\
\text { containing protein 16, partial [G. rostochiensis] }\end{array}$ \\
\hline & & $\begin{array}{c}\text { GPLIN_0012 } \\
58200\end{array}$ & $25107-27756$ & ubiquitin 40 S ribosomal protein $527 a 1$ & no & $\begin{array}{c}\text { GROS_g0756 } \\
8\end{array}$ & protein ubiquitination \\
\hline & & $\begin{array}{l}\text { GPLIN_0012 } \\
58300\end{array}$ & $31187-31435$ & transcribed hypothetical protein & no & & \\
\hline & & $\begin{array}{c}\text { GPLIN_0012 } \\
58400\end{array}$ & 33199-34624 & protein containing SPRY domain & no & GROS_g1418 & $\begin{array}{l}\text { RBP-4 protein [G. pallida]; secreted SPRY domain- } \\
\text { containing protein } 9[\text { G. rostochiensis] }\end{array}$ \\
\hline \multirow{9}{*}{988} & $\begin{array}{ll}\text { SNP- } \\
988_{-}\end{array}$ & $\begin{array}{l}\text { GPLIN_0013 } \\
\quad 23400\end{array}$ & $2535-3808$ & transcribed hypothetical protein & no & GROS_g0156 & \multirow{9}{*}{$\begin{array}{l}\text { protein of unknown function, DUF273 } \\
\text { serine/threonine-protein kinase Nek6, partial [Bos mutus]; } \\
\text { cytokinesis; signal transducer activity } \\
\text { protein BM-MAX-2, isoform i [B. malayi]; K04409 Axon } \\
\text { guidance }\end{array}$} \\
\hline & 7923 & $\begin{array}{c}\text { GPLIN_0013 } \\
23500\end{array}$ & $12021-16917$ & serine:threonine protein kinase Nek6 & no & $\begin{array}{c}\text { GROS_g0133 } \\
4\end{array}$ & \\
\hline & $\begin{array}{l}\mathrm{SNP}_{-} \\
988_{-} \\
8037\end{array}$ & $\begin{array}{l}\text { GPLIN_0013 } \\
23600\end{array}$ & $19109-26588$ & Motor AXon guidance family member ( $\max 2)$ & no & $\underset{7}{\text { GROS_g1007 }}$ & \\
\hline & & & & & & & \\
\hline & $\mathrm{SNP}_{-}$ & & & & & & \\
\hline & $\begin{array}{l}988_{-} \\
8045\end{array}$ & & & & & & \\
\hline & & & & & & & \\
\hline & $\mathrm{SNP}_{-}$ & & & & & & \\
\hline & 988 & & & & & & \\
\hline & SNP_1243 & \multirow{2}{*}{\multicolumn{6}{|c|}{ no predicted gene }} \\
\hline 1243 & 9865 & & & & & & \\
\hline \multirow{3}{*}{1777} & \multirow{3}{*}{$\begin{array}{l}\text { SNP_1777 } \\
\_961\end{array}$} & $\begin{array}{c}\text { GPLIN_0014 } \\
38500^{* *}\end{array}$ & 864-1181 & transcribed hypothetical protein & no & \multirow{3}{*}{$\underset{6}{\text { GROS_g1428 }}$} & \multirow{3}{*}{ cytosol } \\
\hline & & $\begin{array}{l}\text { GPLIN_0014 } \\
38600\end{array}$ & 2326-4922 & maternal protein pumilio & no & & \\
\hline & & GPLIN_0014 & $6616-7313$ & transcriptional regulator ATRX & no & & \\
\hline
\end{tabular}




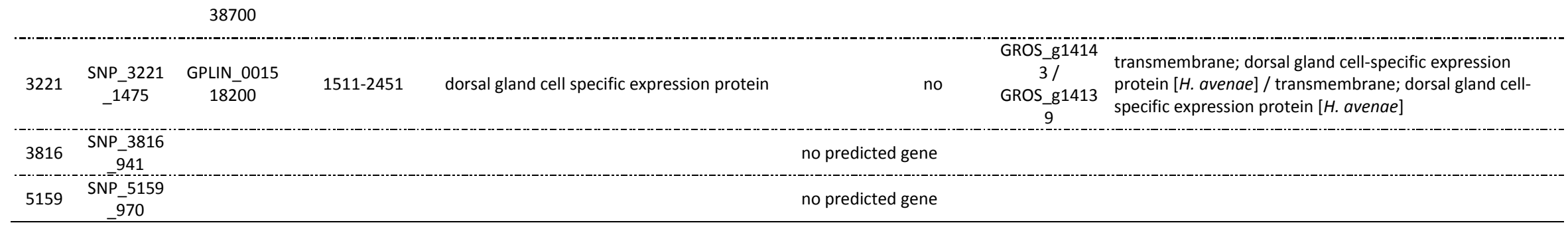

